\title{
WIE ZIJN DE GROOTE ZONDAARS?
}

\section{EFNE VRAAG BETREFFENDE DE BESCHERMING DER SUIKERINDUSTRIE}

IN DE VERSCHILLENDE STATEN VAN FUROPA.

Door den Minister van Financiën is de indiening vau een wetsontwerp in het vooruitzicht gesteld, volgens hetwelk een definitieve regeling van den accijns op de suiker, een einde moet maken aan de reeks van "Nadere Bepalingen" omtrent dit onderwerp, waarmede sedert geruimen tijd het Staatsblad jaarlijks prijkt. Dat met gespannen verwachting dit ontwerp in ons land en ook in onze koloniën wordt tegemoet gezien, valt licht te begrijpen, in aanmerking genomen eenerzijds de vele maatschappelijke belangen, die zich aan onze suikerindustrie vastknoopen, en anderzijds de groote moeilijkheden, die verbonden zijn aan een voor de verschillende belangen bevredigende oplossing. Door de ontzaglijke hoogte, waartoe in de meeste landen van Europa de bescherming der beetwortelsuikerindustrie werd opgevoerd, heeft deze zich uitgebreid tot verre buiten de behoeften der consumtie, en de overproductie, die daarvan het gevolg is geweest, vond hare uiting in de crisis van de jaren 1884-86, zoowel als in die, welke anving in het laatst van het jaar 1894 en onder wier invloed de suikerhandel zich thans nog bevindt. Vooral door deze laatste crisis zijn ook de industrieelen wakker geschud, zich gesteld ziende voor de vraag: waar moet het heen, indien de productie uiet tot staan gebracht wordt? En onder den indruk daarvan worden nu de maatregelen beraamd, die kunnen strekken om de verwarring, in de economische verhoudingen ontstaan, op te heffen: in Duitschland en Oostenrijk zijn voorstellen in overweging tot contingenteering der productie, in Rusland is bereids van regeeringswege een regeling daartoe tot stand gebracht, en ook in ons land, waar de bescherming der beetsuikerfabrikanten in het vorige jaar door de wet van 11 Jan. ECoN. 1895. 
1894 op de helft is verminderd, wordt thans de bovenbedoelde nieuwe regeling verwacht.

Terwijl nu de verderflijke werking van het beschermencle stelsel wellicht nooit zoo duidelijk en klaar der wereld is voor oogen gesteld, als door de geschiedenis der beetsuikeriudustrie in de lantste jaren, terwijl voor deze uitkonst de oogen wel nergens gesloten kunnen worden, en de bekentenis ierler van het hart ınoet, dat het zaak ware de suikerpremiën hoe eer hoe beter af te schaflen, schromen de regeeringen der verschillende landen om daartoe over te gaan, uit vrees voor den ongelijken toestand, die zou geboren worden, indien de andere landen niet volgden. Sen internationale regeling? De illusies omtrent het succes daarvan zijn zeker niet groot meer na de in vroegere tijden opgedane oudervinding: de conventie, die van 1S65-1875 gegolden heeft, bevredigde geen der contracteerende mogendheden, Frankrijk wellicht uitgezonderd, dat zich op zeer eigenaardige wijze de leemten der conventie wist ten uutte te maken. De overeenkomst, die bij het verstrijken van den termijn dezer eerste conventie ter vervanging van deze was ontworpen, werd door de Nederlandsche vertegenwoordiging afgestemd en de pogingen daarna in het werk gesteld om tot een vergelijk te komeu, bleven vruchteloos. Evenmin mocht de Londensche conferentie, die zich van het jaar 1887-89 met dit onderwerp bezig hield, trots de energieke pogingen daartoe in het werk gesteld, er in slagen een conventie te ontwerpen, waarbij de belangen der betrokkeu mogendheden met elkander in overeensteming werden gebracht.

Het mislukken dezer pogingen is door zeer natuurlijke oorzaken te verklaren, oorzaken, die ook voor het vervoly geen beter resultaat doen verwachten. Waren het slechts directe uitvoerpremiën, in verband met hooge invoerrechten, waardoor de bescherming werd verkregen, de mogelijkheid zou bestaan om, vooral in dezen tijd, nu de noodlottige gevolgen der bescherming zoo duidelijk aan het licht zijn getreden, eeustemmigheid omtrent de afschaffing daarvan te verkrijgen. Maar in alle landen zijn deze premiequaesties zoozeer ineengeweven met de accijnsregeling, de complicaties, die zich daarbij voordoen, zijn zó talloos, de toestandeu zijn zóó verward, het hier vigeerende stelsel yrijpt op zoo wonderbaarlijke en vaak onna- 
speurbare wijze ineen met de stelsels, die elders in werking zijn, de onderscheidingen tusschen oorzaken en gevolgen liggen menigmaal zóó in het cluister, dat het schier een hopelooze taak schijut daariu door interuationale regeling orde te brengen. Aan de haud van de geschiedenis van den suikeraccijns, zoo in ons land als in andere liuden, ruag de meening worden uitgesproken, dat er wellicht geen haudelsartikel te bedenken is, dat uit een practisch oogpunt minder geschikt is voor accijnsheffing dan juist de suiker. Wint de and van dit artikel, dat als grondstof in het land wordt geproduceerd en tevens tot product, (geraffineerd) in liet land wordt verwerkt, dat in het land wordt ingevoerd en uit het land wordt geëxporteerd en dat èn ils grondstof èn als̀ product voorkoint in tallooze vormen en soorten allen voorstellende verschillende warden, brengt inede, dat men bij de accijnsheffing niet kan ontloopen een heirleger van wetten en bepalingen van wetten, wanmede de koophandel zoo slecht gediend is en warrbij de rechtvaardigheid tegenover allen gewoonlijk zoo moeilijk is toe te passen.

In ons land bestaat de suikeraccijns sedert het jaar 1819; meer dan driekwart eeuw is dus verloopen sedert Gijsbert Karel van Hogendorp bij de behandeling van dit onderwerp zijn waarschnwende stem deed hooren in 's lauds vergaderzaal en deze woorden sprak: "Ik bezweer U Nederlanders, mijn geliefde "landgenooten, vertegenwoordigers der natie, schort Uw oordeel "op. Ik verzoek $Z$. M. eerbiediglijk de conceptwet in nadere "overweging te nemen." Blijkt uit deze woorden hoezeer van Hogendorp de gevolgen van dien aucijns vieesde, toch kan niet beweerd worden, dat in dien tijd de wijdstrekkende gevolgen dezer accijnswet te voorzien waren; van Hogendorp zelf toch betitelde nog in het jaar 1816 de beetsuiker als "het ellendig surrogaat van Fransche revolutionaire uitviuding", wel een bewijs hoe weinig hij in dat "ellendige surrogaat" het product zig, dat eemual bestemd zou ziju ow het exotische product naar de kroon te steken, ja het grootendeels vau de Europeesche markt te verdrijven en daarmede een nieuw element bij de accijnsquaesties in te lijven: dat der biunenlandsehe productie. Maar wat van Hogendorp en de zijnen wèl voorzien hebben en wairin zij door de geschiedenis zijn gerechtvaardigd, is dit: dat de suikerhandel zich zou gekneld voeleu loor de 
banden hem door de accijnswet aangelegd, banden waaraan hij zich wellicht geleidelijk gewend heeft, mar die niettemin zijn vrije en gezonde ontwikkeling hebben belemmerd Het accijnsstelsel met zijn contrôle, voorschriften en verbodsbepalingen, met zijn privileges ter eener, zij̄n onbillijkheden ter anderer zijde heeft in den haudel consideraties ingelijfd, die, bij normalen toestand daaraan vreemd zijn en den fabrikant dwingen zijn keuze met betrekking tot de grondstof, die hij te gebruiken, het fabrikaat, dat hij te vervaardigen heeft, ja de wijze van fabricage zelf, te bepalen uit motieven gelegen buiteu de eischen van den handel en van de techniek. Onder het vigeerende stelsel is de wet verlangd tot een speelbal tusschen concurreuten, diengenen het meest ten voordeel, die daarmede het handigst weten te manoeuvreeren. Illustraties tot dit thema zijn in de geschiedenis van den suikerhandel van ons land in deze eeuw in menigte te vinden, maar hoe rijk aan leeringen historische herrinneringen op dit gebied mochten zijn, zij zijn allerminst geschikt om slechts ter loops en als met enkele pennestreken te worden geschetst, en kunnen dus hier geen plaats vinden, waar het doel is den tegenwoordigen toestand in het oog te vatten.

Alleen zij het vergund nog even af te dwalen naar een verder verleden en een stem op te roepen, die sinds lang gesmoord is in het stof der archieven. Het is een stem uit de eerste helft der $17^{e}$ eeuw, toen de nooden der schatkist der Vereenigde Provinciën ook drongen tot het heffen van nieuwe belastingen. Zoo verschenen van 1629 tot 1641 , op de punten van beschrijving der Staten van Holland, onder allerlei vormen ontwerpen tot regeling van een verbruiksbelasting op de suiker. Maar telkens stuitten deze af op de tegenkanting der Heeren van Amsterdam, die, volgens het mandat hunner vroedschappen, de desbetreffende voorstellen, zoo vaak die ter tafel kwamen, net de grootste hardnekkigheid en in de gewone bondige termen verwierpen, als: "impracticabel, als nood"zaeckelyk diversie van neeringe medebrengende, en als pure "vexatiën wesende onderworpen." Al ligt het niet in de bedoeling, om toestanden van toen terug te brengen op toestanden van thans, toch moge hier, terwijl wij ons bevindeu te midden van de vexatiëu, die gedurende driekwart eeuw een accijnswet 
in liaal gevolg heeft gesleept, als in het voorbijgaan een saluut, worden gebracht an de Heeren van Amsterdau, die met hun practischen blik die vexatiën voorzagen, en op grond daarviu, alsook uit vrees voor "diversie van neeringe" , het schrikbceld der $17^{\text {de }}$ eeuwsche Amsterdamsche kooplieden, zich met hand en tand verzetten tegen de invoering eener suikeraccijuswet.

En hiermede een eind aan retrospectieve beschouwingen en teruggekeerd tot het tegenwoordige, dat een tooneel te ianschouwen geeft wel de aandacht waardig, al kan het geen hoog denkbeeld geven van hedendaagsche economische toestanden. Voorzeker zal ieder, die met kennis van zaken en onbevooroordeeld den toestand op het gebied der suikerwetgeviug in Europa beschouwt, tot de erkenning moeten komen, dat die toestand vicieus is tot in merg en been. Maar hoe te geraken uit het netwerk, waarin men verward is? De regeering van het land, dat daartoe een poging wil wagen, moet knoopen doorhakken, waarbij echter de industrie, aan een ongelijken strijd blootgesteld, gevaar loopt ten onder te gaan. Om den toestand aanschouwelijk voor te stellen, een voorbeeld, het allernieuwste:

Duitschland heeft getoond tot afschaffing der premiën te willen geraken door in 1892 de belasting naar de verwerkte bieten, waarin een belangrijke premic lag opgesloten, te vervangen door een fabrikaatsbelasting en daarentegen een open, maar afloopende uitvoerpremie in te voeren; deze premie zou 31 Juli 1895 verminderd en in 1897 afgeschaft worden. Toen de $31^{\text {ste }} \mathrm{Juli} 1895$ naderde beleefde men een tijd, waarin ten gevolge van de crisis de geheele wereld onder den indruk was van de wenschelijkheid der afschaffing van de premiën, die de overproductie veroorzaakt hadden; maar niettemin herriep in dienzelfden tijd de Duitsche Rijksdag met overgroote meerderheid de wettelijke bepaling, waarbij de vermindering dier premiën was vastgesteld. Ev thans brengen de dagbladen de tijding, dat de Duitsche regeering een wetsontwerp heeft ingediend, waarbij een belangrijke verhooging der uitvoerpremiën wordt voorgesteld. Zóó is de toestand: de omstandigheden eischen een weg te bewaudelen lijnrecht tegenovergesteld aan de richting, die men als de goede erkent, en waar het groote woord van Gogel: "wat niet staan kan moet 
vallen", uog soms in herimmering wordt gebracht, mag wel tevens gewezen worden op groote voorzichtigheid in de toepassing daarvan bij den tegenwoordigen staat van zaken.

Maar een vraag die te grooter belangstelling verdient, naarmate de oplossing minder voor de hand ligt, is deze: welke hoogte hebben de premiën in de verschillende Europeesche landen bereikt, en welken rang bekleedt daarbij in het bijzonder ons land? Bij de behandeling in de Tweede Kamer van het ontwerp, dat 11 Jan. 1894, wet is geworden, heeft de Minister van Financiën, de heer Pierson, wat ons land betreft, uitspraak gedaan door te verklaren: "Tot de groote zondaren op dit gebied" (der bescherming) "behooren wij." Maar tegelijk heeft de Minister aan de beetsuikerindustrie een zware operatie doen ondergaan, waarbij haar op eens de helft der bescherming van voorheen werd ontnomen en waardoor, zooals straks zal blijken, ons land plotseling een paar sporten op den beschermingsladder is afgedaald. Hierbij kan geconstateerd worden dat de patiënt de operatie met veel zelfbeheersching heeft ondergaan; moge het een blijk zijn, dat hare krachten sterk genoeg waren!

"Terugkomende op de vraag: "wie zijn de groote zondaars?" zij opgemerkt, dat bij de behandeling der bovengenoemde wet de Minister van Financiën wèl aanwijzingen gaf, hoe wij stonden tegenover de twee groote suikerproduceerende landen van Europa: Duitschland en Oostenrijk, maar de parallel niet trok met de andere suikerproduceerende landen van den eersten en met die van den tweeden rang. Was het van het standpunt van den Minister zeker juist, ter vermijding van allerlei vermoeiende details dit punt voor de kamer slechts in den breede te behandelen, toch kan het zijn nut hebben een beeld te ontwerpen van den tegenwoordigen toestand in geheel Europa, een beeld, waarin ook de positie van ons land moet in het oog vallen. Bij de zeldzame complicaties, die zich overal in de suikerwetgeving voordoen, is het geen gemakkelijke zaak om tot zuivere resultaten te geraken en van de onvolkomenheden en onnauwkeurigheden, die overblijven, moet zeker wel degeen het meest overtuigd zijn, die trachtte zulk een resultaat te verkrịgen. Met andere woorden : de cijfers, die bierna volgen, zijn er verre van verwijderd met mathematische juistheid uit te 
drukken den toestand in ieder land, mair slechts bestemd om ten naaste bij de plaats aan te geven, die de suikerhandel, -industrie, -wetgeving, en -protectie van ieder land in het geheele samenstel inneemt.

In alle landen van Furopa, Engeland uitgezonderd, bestaat eeu accijns op de suiker, d. w. z. een belasting op de binnenlandsche consumtie van dit artikel. In all die landen geschiedt de heffing aan den oorsprong, zooals het heette in het systeem, dat ook bij ons in 1819 werd ingevoerd, d.w.z. ter plaatse waar de suiker in het land wordt gebracht, dus, hetzij aan de grenzell, zoo zij uit het buitenland wordt ingevoerd, hetzij ter plaatse waar de ruwe suiker in het binnenland wordt vervarardigd. In al die landen, eindelijk, is op eene of andere wijze aan deze heffing verboudeu een bescherming voor de binnenlandsche industrie. Deze bescherming is van drieërlei aard, te weten:

10. Bij den invoer van suiker uit den vreemde wordt geheven een surtaxe boven den door de binnenlandsche fabrikanten te betalen accijns, een bescherming dus, die ten doel heeft ten bate der binnenlandsche fabrikauten den invoer van het buitenlandsche fabrikaat te bezwaren of ook onmogelijk te makeụ.

$2^{\circ}$. de aanslag voor den accijus van den binnenlandschen fabrikant wordt zoodanig geregeld, dat die blijft be ne den het accijnsbedrag der werkelijke productie; het verschil vormt de premie voor den fabrikant.

$3^{\circ}$. Uit de opbrengst van den suikeraccijus wordt aan de fabrikanteu een premie uitgekeerd over de suiker, die an de grenzen wordt uitgevoerd. Deze is de zoogenaamde open of directe uitvoerpremie.

In de meeste landen zijn combinaties dezer drie systeemen in toepassing, zooals hieronder wordt aangegeven:

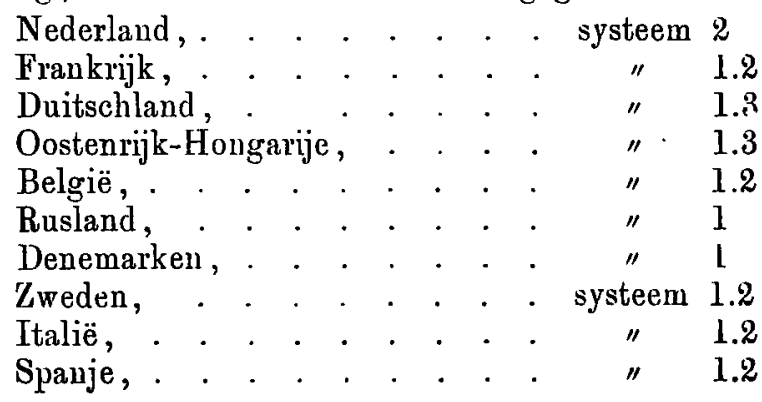


Hel zal noodig zijn vooraf omtrent de surtaxe eenige opmerkingen in het midden te brengen, omdat haar werking in de practijk van geheel anderen aard is, dan men bij oppervlakkige beschouwing zou veronderstellen. Volgens een Belgisch staathuishoudkundige wordt de bedoeling en tevens de rechtvaardiging der surtaxe aangegeven door deze definitie: "C'est la restitution à la frontière des primes, que certains pays accordent aux fabricants pour exporter leurs produits." Moge dit in beginsel zeer fraai klinken, in de practijk blijft echter van dit beginsel niet veel over. Vooreerst gaat het geheel verloren voor die landen, die de surtaxe heffen en zelve hooge uitvoerpremiën verleenen. Een surtaxe b.v. door België geheven om de premie vau Duitschland te dekken, welks suikerwetgeving een veel geringer premie in zich sluit, kan zeker allerminst op het aangevoerde beginsel steunen. Bovendien hebben de voornaamste suikerproduceerende landen de surtaxe veel hooger gesteld, dan gemotiveerd kan zijn door haar bestemming ter dekking van buitenlandsche premiën, ja die zóó vor opgevoerd, dat zij gelijk staan, met een verbod van invoer. Inderdaad blijkt, dat de invoer van beetsuiker uit den vreemde in Frankrijk, Duitschland, Oostenrijk, Hongarije en Rusland zóó gering is, dat die bijkans als nihil kan worden beschouwd.

Wat is nu het effect van deze surtaxe op den suikerprijs ter binnenlandsche markt, welk voordeel spruit daaruit voor de binnenlandsche fabrikanten voort? Indien zij dien prijs kunnen opvoeren tot het bedrag, waarvoor het buitenland kan leveren, vermeerderd met dat der surtaxe, dan treedt deze laatste in haar vollen omvang op als winst voor de fabrikanten. Maar te dezen opzichte heeft de practijk van den handel gansch andere uitkomsten te voorschijn geroepen voor die landen, wier productie de binnenlandsche consumtie te boven gaat. Voor dit overtollige toch moet plaatsing gezocht worden aan de buitenlandsche markt tegen den daar geldenden, d. w. z. wereldmarktprijs. Tegelijk wordt echter een débouché voor het surplus gezocht in het binnenland en daardoor ziet men de binnenlandsche noteeringen weldra teruggebracht tot die in het buitenland en dat niet slechts voor het overtollige, maar, de practijk leert het, voor de geheele productie.

Deze loop van zaken zou slechts kunnen worden tegengegaan 
door een krachtig syndicaat der fabrikanten, zooals bv. in Ruslnnd bestaat, waarover straks nader. Buiten het beslaan van zulk een syndicaat kan beweerd wordeu, dat in alle landen; waar de productie het voor de consumtie benoodigde overschrijdt, trots het bestaan van een surtaxe, hoe hoog ook, de noteering ter binnenlandsche markt ongeveer gelijk staat met den wereldmarktprijs (Londen, Hamburg). Onder die omstandigheden roept dus een hooge surtaxe wèl.een monopolie der fabrikanten op) de binnenlandsche markt in het leven, zonder dat echter aan dit nonopolie voordeelen voor de fabrikanten, noch schaden voor de consumenten verbonden zijn. Voor de landen, die niet behoeven uit te voeren, als Italië, Spanje en Zweden zijn de uitkomsten geheel anders, zooals hieronder blijken zal. Wat Zweden betreft, dit land staat in den tegenwoordigen tijd door de belangrijke toename der productie op de kentering en het zal belangrijk zijn te aanschouwen hoe de loop van zaken dáár zal zijn, wanneer, zooals te voorzien staat, binnenkort de productie in dat land cle consuntie overschreden zal hebben.

Dit wat betreft de surtaxen. Aangaande de premie sub. 3 bedoeld, moet worden opgemerkt, dat, hoewel deze uit 's rijksschatkist slechts wordt verleend over den uitvoer, daarin echter ligt opgesloten een premie tot gelijk bedrag over dat gedeelte der productie, dat in het land blijft. Immers de fabrikanten zouden hun geheele productie kunnen uitvoeren, ten einde over die geheele productie de premie te ontvangen; de raffinadeurs dus moeten om de hoeveelheid, die zij wenschen te verwerken en die zij wegens de surtaxe niet uit het buitenland kunnen betrekken, in handen te krijgen, zich laten welgevallen boven den marktprijs nog de premie te betalen, tot een bedrag als dic door het rijk bij den uitvoer wordt verleend. Is dus de open uitvoerpremie b. v. vastgesteld op f 1.- per 100 kilo, dan ontvangen de fabrikanten dit bedrag, voor zoover betreft den uitvoer, van het rijk en wat betreft de consumtie, van de raffinadeurs, die het weder den consumenten in rekening brengen. Men ziet hoe energisch dоor den handel ingegrepen wordt in de bepalingen der wet, waardoor hare bedoelingen hier worden verijdeld, ginds wijdere strekking ontvangeu, in de meeste gevallen worden gewijzigd.

Deze opmerkingen in het oog houdende worde getracht te 
berekenen, hoe hoog de premie is, die in het belnstingstelsel van ieder land in het bijzonder voor de beetsuikerfabrikanten ligt opgesloten, terwijl zoodanige statistische gegevens omtrent invoer, uitroer en productie, en andere mededeelingen daaraan zullen wordeu toegevoegd, die kunnen strekken om het standpunt van ieder land in den suikerhandel aan te duiden. Voor Rusland, Denemarken, Zweden, Italië en Spanje zal het gelden de berekening der totale practische premie, $d$. w. z. der premie, inclusief het winstberlrag, dat zich ten gevolge van de snrtaxe, uitdrukt in prijsverhooging der suiker op de himenlandsche markt. Voor Frankrijk, Duitschland, Oostenrijk en België vertoonen de noteeringen van $r u$ we suiker op de binnenlandsche markt geen of slechts geringe verschillen met den wereldmarktprijs en is van geen surtaxewinst sprake, of treedt deze slechts op den achtergrond. In Nederland, waar geen surtaxe bestaat, is van zelf ook alle sirtaxewiust buitengesloten.

\section{NEDERLA N D.}

De acoijns op de suiker is in Nederland gesteld op 27 gulden per 100 kilo droge witte broodsuiker, d. w. z. suiker vill ongeveer 100 pCt. Deze nceijns wordt in rekening gebracht voor de geimporteerde suiker bij den invoer en voor de suiker van binnenlandsch fabrikaat door den aanslag der beetsuikerfabrikanten naar de hoeveelheid en de dichtheid van het verwerkte sap. Die aanslag bedroeg voorheen per hectoliter sap en per graad dichtheid bij 15 graden C., $14.50 \mathrm{gram}$ droge witte broodsuiker, maar is volgens de wet vall 11 Jan. 1894 wet 12 pCt. vermeerderd. Voor het sap, dat na 1 Januari verwerkt wordt, bedraagt de aanslag slechts 1400 gram plus $12 \mathrm{pCt}$. Voor de fabrikanten, die van het osuose procédé gebruik maken, wordt de aanslag met $l_{\frac{1}{2}}$ pCt. verhoogd, indien dit procédé alleen bij het bewerken van het derde product wordt toegepast, en anders met $5 \frac{1}{2} \mathrm{pCt}$.

Tusschen deze wijze van aanslag en een andere naar de wérkelijke productie wordt den fabrikant de keus gelaten, maar darr de laatstbedoelde in geen der beetsuikerfabrieken toepassing vindt, kan hierover verder worden gezwegen. 
IIet bedrag wanrtoe de premie, die in den ainslag naar de dichtheid $\mathrm{un}$ de hoeveelheid van het sap ligt opgesloten, kan stijgen, wordt beperkt doordien het minimum van de opbrengst van den accijns is vastgesteld op 8.500 .000 gulden in 1894 en 1895 en op 8.650 .000 gulden in 1896. Het ontbrekende ann die opbrengst moet over de beetsuikerfabrikanten worden omgeslagen, welk geval zich echter nog niet heeft voorgedaan, dair in 1894, de accijns opbracht 9.037.606 gulden. De aansprakelijkheid der beetsuikerfabrikanten voor een opbrengst beneden het minimum, wordt beperkt door de bepaling, dat in 1895 en 1896 geen omslag plaats heeft, indien de gezamenlijke hoeveelheid droge witte broodsuiker, wanrvoor de fabrikanten zijn aangeslagen 44.000.000 kilo niet te boven gaat. Bij een hooger aanslagstotaal bedraagt de onslag ten hoogste 3.40 gulden per 100 kilo over het meerdere.

Bij den uitvoer heeft afschrijuing ran den accijns plaats op de rekening wegens met krediet voor den accijns ingeslagen of vervaardigde suiker. Ter herleiding van de ruwe suiker tot droge witte broodsuiker wordt het gehalte van suiker, door polarisatie gevonden, verminderd net 4 maal de asch en 2 maal de glucose. Van dit bedrag wordt ter bepaling van het werkelijk rendement voor alle beetsuiker nog $1_{\frac{1}{2}} \mathrm{pCt}$. en voor rietsuiker 21 pCt. afgetrokken als raffinageverlies, mits het geen suiker geldt van meer van $99 !$ pCt.

Surtaxen, invoerrechten boven den accijns, worden niet geheven, zoodat in dit opzicht het buitenlandsche product met het binnenlandsche gelijkstaat.

Een maatregel, die ten doel heeft te controleeren, hoe de werkelijke productie, zoo der beetsuikerfabrieken, als der raffinaderijen staat tegenover het wettelijk aangenomen rendement, ter bepaling met andere woorden van de overponden of het excedent, is in Nederland eerst in het jaar 1594 ingevoerd en resultaten daaromtrent zijn nog niet medegedeeld. Derhalve zijn, in tegenstelling van b.v. Frankrijk, de excedenteu der Nederlandsche fabrieken niet unet juistheid bekend. Toch zijn van officieele zijde daaromtrent eijfers medegedeeld, waarop zich een, zij het dan meer of minder nauwkeurige, berekening laat baseeren. Zoo nam de Minister van Financien, de heer Pierson, bij zijn verdediging van de wet op de ver- 
honging van den aanslag der suikerfabrikanten met $12 \mathrm{pCt}$. (wet van 11 Jan. 1894) de gemiddelde overponden in de campagne $1891-92$ op $25.2 \mathrm{pCt}$. en in $92-93$ op $24.13 \mathrm{pCt}$. van den aanslag aal. Op grond dezer opgaven neme men het gemiddelde excedent aan op 24 pCt. van den aanslag. De aansling voor het werkjaar 1893-94 bedroeg 50 millioen kilo droge witte broodsuiker, waarvan 24 pCt. bedraagt 12 millioen kilo, die, de overponden vertegenwoordigende, correspoudeeren op een accynswinst van $12.000 .000 \times \frac{27}{1(k)}$ $=3.240 .000$. gulden. De geheele productie, van droge witte broodsuiker tot ruw suiker herleid ( $\$ 8: 100$ ), en inclusief de overponden op 70.4j millioen kilo berekend, bedroeg de premie dus 4.60. gulden per 100 kilo werkelijke productie. Bij deze berekening is ter verduidelijking het cijfer voor den aanslag ingelascht, hoewel het l'esultaat, bij aanname van cen vast gemiddeld excedent, vau dien aanslag onafhankelijk is.

De toestand, zooals die hier voor de campagne 1893-94 is angenomen, is echter door de sedert het begin der campagne 1894-95 ingevoerde wet zeer belangrijk gewijzigd. Door verhooging van deu aanslag met 12 pCt. zijn namelijk de overponden op de helft teruggebracht. Inmers een aanslag van 100 wordt daardoor tot 112 opgevoerd, zoodat van de productie van $100+24=124$ thaus overschieten 124 $112=12$ overponden, d. i. de helft van voorheen. Hoor die wet is dus de premie op de helft, d. i. gemiddeld $\mathbf{2 . 3 0}$ gulden per 100 kilo ruwe suikor teruggebracht en daarmede Nederland belangrijk teruggedrongen in de rij der beschermende mogendheden, waarin het vroeger een eerste plats innam.

Het standpunt van Nederlands suikerhaudel, wordt door de volgende statistische cijfers angeduid:

1893-94 1894-95

Millioen $\mathrm{K}^{0}$. Millioen $\mathrm{K}^{0}$.

Productie beetsuiker (anslag +24 pCt.) 70.4 76.1

$1893 \quad 1894$

Millioen $\mathrm{K}^{0}$. Millioen $\mathrm{K}^{0}$.

Invoer tot verbruik ruwe suiker . . . $100.2 \quad 106.3$

Invoer tot verbruik geraftineerde suiker . $\quad 9.0 \quad 11.2$

Uitvoer uit het vrije verkeer ruwe suiker $6.9, \quad 5.2$

$\begin{array}{llll}\text { Uitvoer uit het vrije verkeer geraff. suiker } & 105.6 & 109.9\end{array}$ 
In deze eijfers spreekt zich de afwezigheid van een surtaxe hier te lande vooral uit door het hooge eijfer voor den invoer tot verbruik van ruwe suiker. Al deze suiker wordt in de Nederlandsche raffinaderijen verwerkt en door deze als geraffineerd in consumtie gebracht of, en wel voor een belangrijk gedeelte, geëxporteerd. Nochtans genieten de raffinadeurs geen belangrijke bescherming, maar wordt vrij algemeen angenomen, dat, moge bij de tegenwoordige accijnsregeling ook hier en daar nog een percentfractie ten voordeele der raffinadeurs afvallen, hunne premie, sedert de invoering van den aanslag naar de titrage der door hen ingeslagen suiker in 1884, tot een minimum is teruggebracht '). Deze uitspraak zouden wij niet durven uitstrekken tot de raffinaderij, die het Steffen's procédé tot het winnen van gekristalliseercle suiker uit melasse toepast. Indien hier onbeslist wordt gelaten in hoeverre de tegenwoordige, van jaar tot jaar verscherpte condities, nog, als voorheen, een belangrijke accijnswinst medebrengen, het is wegens de moeilijkheid oln tot vertrouwbare cijfers te geraken en zeker niet omdat de zaak onbelangrijk is, daar boveubedoelde raffinaderij in 1893 ongeveer een derde gedeelte verwerkte van de gezamenlijke Nederlaudsche raffinaderijen.

\section{FRA N K RIJ K.}

De accijns op de suiker is in k'rankrijk gesteld op 60 francs per 100 kilo geraffiueerd. De bepaling van het rendement van ruwe en geraffineerde suiker geschiedt in Frankrijk, even als by ons ${ }^{2}$ ), door van de polarisatie 2 maal de glucose en 4 maal de asch en bovendien nog $1 !$ pCt. voor raffinage verlies af te

1) Hierbij zij opgemerkt, dat, daar de overponden der beetsuikerfabrikanten buiten de accijnsrekening staan, deze overponden, wil het voordeel van den vrijdom van accijns voor de fabrikanten niet verloren gaan, slechts bij de Nederlandsche raffnadeurs kunnen ter markt gebracht worden. Hiervan maken deze gebruik om minder voordeelige verkoopcondities te stellen, waardoor een deel van de premie der fabrikanten op de raffinadeurs overgaat. $\mathrm{Er}$ moet echter van afgezien worden den zelrer niet zeer belangrijken invloed dezer omstandigheid in cijfers uit te drukken.

?) Zie blz. 851 . 
trekkeu. Wail hier ouder het hoofd "Frankrijk" verder van suiker, zouder verdere omschrijving sprake is, wordt dararmede bedoeld: suiker op deze wijze tot geraftineerd herleid.

De ianslay der beetsuikerfabrikanten geschiedt naar het gewicht der verwerkte beetwortels in die! voege, dat den fabrikant voor een bedrag an suiker overeenkomende met 7.75 $p C t$. der verwerkte beetwortels de volle accijns van 60 francs per 100 kilo wordt in rekening gebricht. Voor het excedent, dat tengevolge van de exercice, die in de Fransche beetsuikerfabrieken wordt aitgeoefend, bij den liscus nauwkeurig bekend is. wordt de belasting met $\left.\jmath^{\prime}\right) \mathrm{pCt}$ verminderd, dus een premie vau 30 francs per 100 kilo toegekend, echter slechts voorzoover de werkelijke productie liet bedrag van 10.5 pCt. der beetwortels niet te boven gaat. $V_{\text {in }}$ de productie boven 10.5 pCt. wordt de helft belast met 60 francs, $d$. i den vollen accijns en de audere helft met 30 fraucs per 100 kilo. Behalve dit erkent de wet nog eeu ander stelsel, en zij laat den fabrikanteu de vrije keuze welk der beide zij op hun bedrijf weuschen toegepast te zien. Bij dit tweede stelsel wordt over 15 pCt. van de geheele werkelijke productie van den fabrikint, de belasting met 50 pCt. verminderd, dus een premie van 30 fruucs per 100 kilo berekend.

Met behulp van de juist gepubliceerde productiecijfers voor de campagne 1894- -95 kan de volgende berekening omtrent de premie gedurende dat tijdsverloop worden opgesteld.

De greheele productie der abounementsfabrieken bedroegr in droge witte broodsuiker . . . . . . j94.j12.471 kilo.

De aunslag à $7.75 \mathrm{pCt}$. der verwerkte beetwortels bedroeg. . . . . . . . 4.54.595.029 "

Productie boven $7.75 \mathrm{pCt} . \quad . \quad . \quad .139 .914 .442$ kilo.

De hieronder begrepen hoeveelheid, vertegenwoordigende de helft der productie boveu de 10.5 pCt., bedroeg. . .

Blijft voor excedenten, waarvoor slechts de halve accijns betaald wordt, . . 136.634.102 kilu.

De geheele productie der niet geabonneerde fabrieken, diarouder de geringe verwerking der distilleerfabrieken begrepes, bedroeg in droge witte broodsuiker 109941.637 kilo, Wialr- 
van dus de excedenten ì $1 \check{\text { pCt. }}$, betalende den halven accijns, bedragen. . . . . . . . . . . . 16.491.24j kilo.

excedent der abonnementsfabrieken . 136.634.102" totaill excedent. . . $153.125 .347 \mathrm{kilo.}$

Hierover wordt nu een premie ter warde van den halven accịns, dus à 30 francs per 100 kilo genoten, makt 1.j31.253 $\times 30=45.937 .590$ trancs of, over cle geheele productie omgeslagen, . . . . . . . . . $45.9337 .590 \times 100$

\section{$704.454 .100^{-}=$}

6.52 frrancs per 100 kilo droge witte broodsuiker of 5.74 fruncs per 100 kilo ruwe suiker (88 : 100)

Gedurende de vorige jaren, waarin dezelfde regeling heeft gegollen, wareu de premiëu, op dezelfde wijze berekend, per 100 kilo ruwe suiker:

$$
\begin{aligned}
& 1891-92: 6.29 \text { fraucs } \\
& 1892-93: 5.14 " \text { " } \\
& 1893-94: 5.59 " \text {, dit is gemiddeld in }
\end{aligned}
$$

de liatste 4 jaren: 5.69 franes per 100 kilo ruwe suiker.

Een nagenoeg even groote bescherming als de Frausche beetsuiker, geniet de rietsuiker uit de Frausche koloniën, die op de Fransche markt eeu niet onbelangrijke rol speelt eu in 1894 tot een hoeveelheid van 107 millioen kilo werd ingevoerd. Voor deze suiker worlt nl. het halve recht van 30 francs per 100 kilo geheven voor zoodanig gedeelte van den invoer als overeeukomt met het aandeel der excedenten van de beetsuikerfabriekeu gedurende het laatste campagnejaar in de geheele productie. Loo bedroegen volgens vorenstaande cijfers de excedenten der beetsuikerfabrieken in de campagne 94-95, 21.2 pCt. van de geheele productie, en wordt dus voor de campagne 95-96 over $21.2 \mathrm{pCt}$. der ingevoerde suiker uit de Fransche koloniën slechts 30 francs per ì00 kilo invoerrecht betaald. Deze maatregel is genomen, niet alleen ten behoeve der koloniën, maar ook vau de raffinaderijen in de haveuplaatsen Nantes, Marseille, Havre en Bordeaux, die de koloniale suiker niet kunuen missen.

De surtaxe bedraagt in Frankrijk 7 franes per 100 kilo op suiker van Europeeschen oorsprong en vau 98 pCt. rendement of uninder. Zij bedraagt 12 francs op alle vreemde ruwe suiker hetzij Europeesch of koloniaul vau houger rendement dan 
98 pCt., en 8 francs op alle vreende geraffineerde suiker. ') Alle overige suiker, dat is alle suiker uit de Fransche koloniën en die uit de vreemde koloniën van 98 pCt. rendement of minder is vrij van surtaxe. De kandij is hierbij buiten besohouwing gelaten.

De surtaxe op de beetsuiker stelt de fabrikanten in Frankrijk, die zich in meerdere of mindere mate gesyndiceerd hebbeu, in staat den prijs hunner suiker op de Parijsche markt te houden op ongeveer 3 franes boven den wereldmarktprijs, zooals de prijscouranten uitwijzen. Dit bedrag is als hun surtaxewinst te beschouwen, en wordt niet genoten van den uitvoer, die in 1894 161.3 millioen kilo bedroeg; op een productie van 800.5 millioen kilo wordt deze surtaxewiust dus 2.40 francs per 100 kilo ruwe suiker.

Bij dezen staat van zaken werden de volgende resultaten verkregen :

1893-94 1894-95 millioen $\mathrm{K}^{\circ}$ millioen $\mathrm{k}^{\circ}$

Binnenlandsche productie van beetsuiker,

op ruw suiker berekend $(88: 100) \cdot .656 .0 \quad 800.5$

\begin{tabular}{|c|c|c|c|}
\hline & 1893 & 1894 & \\
\hline Invoer vreemde rietsuiker & 31.5 & 53.5 & בֶ \\
\hline Invoer suiker uit de Fransche koloniën & 111.4 & 107.1 & \\
\hline Invoer vreemde beetsuiker. & Nihil & Nihil & \\
\hline Invoer geraffineerde suiker. & 0.5 & 0.5 & \\
\hline Uitvoer ruwe suiker uit de Fransche koloniën & 1.9 & 2.5 & \\
\hline Uitvoer ruwe suiker van binnenl. prod. & 153.2 & 161.3 & \\
\hline Uitvoer geraffineerde suiker & 110.3 & 1285 & \\
\hline Uitvoer basterden. . . . & 5.0 & 5.] & \\
\hline
\end{tabular}

Als resultaat der Fransche wetgeving leest men uit deze cijfers: de vreemde beetsuiker wordt geheel van de Fransche markt geweerd; daarentegen vindt de suiker uit de Fransche koloniën in ruime mate plaatsing, terwijl ook koloniale suiker van elders, zij het in meer bescheiden hoeveelheden, wordt

1) Voor geraffineerd bestaat een «tarif général» en een «tarif minimum»; volgens het eerste is de surtaxe 12 francs; volgens het tweede 8 francs; dit laatste komt hier slechts in aanmerking, daar het wordt toegepast op den invoer uit alle Enropeesche staten, behalve Italië, Portugal en wellicht Montenegro. 
toegevoerd. Ook de invoer van geraffineerde suiker is vall weinig beteekenis, terwijl daarentegen de uitvoer van suiker, zoo in den vorm van ruw als geraffineerd, een zeer belangrijke hoogte heeft bereikt.

Wat betreft de raffinadeurspremiën, het schijnt, dat de mogelijkheid op het bestaan daarvan tot een aanmerkelijk bedrag, heeft opgehouden, sedert op 1 Sept. 1893 de wet in werking is getreden, waarbij de raffinaderijen aau een strenge exercice werden ouderworpen en bepaald werd, dat van alle excedenten, die zouden blijken voort te vloeien uit te laag aangenomen rendement, het volle recht van 60 francs moet betaald worden. Indien deze fabrieken zich nochtans in een staat vau grooten bloei bevinden, hebben zij dit ten deele te danken aan hare groote tinanciëele kracht, die haar tot speculatie in staat stelt. Maar bovendien is het den raffiuadeurs gelukt door zich te syudiceeren en met behulp van de surtaxe, den prijs van geraffineerd op de binuenlandsche markt tot gemiddeld 5 franos boven den wereldmarktprijs op te voeren, zooals uit een reeks noteeringen te Parijs, vergeleken met die te Londen, is opgemaakt. Genoemd bedrag komt dus als surtaxewinst den Franschen raffinadeurs ten goede over hunne leveringen voor het biunenland.

\section{O OSTENRIJK - H O N G A R IJ E.}

De accijns op de suiker bedraagt, onafhankelijk van haar zuiverheid, 11 florijnen per 100 kilo en wordt geheven naar de werkelijke productie, zoodat daarin geen premie verscholen ligt. Het invoerrecht bedrangt voor ruwe suiker beneden $\mathrm{N}^{\circ} 19$ 15 tlorijnen en voor ruwe suiker No 19 en daarboven, alsmede voor geraffineerde suiker 20 florijnen, zoodat van de eerste rubriek wordt geheven een surtaxe van 4 florijnen en van de tweede 9 florijnen, alles per 100 kilo.

Bovendien worden de volgende uitvoerpremiëu toegekend:

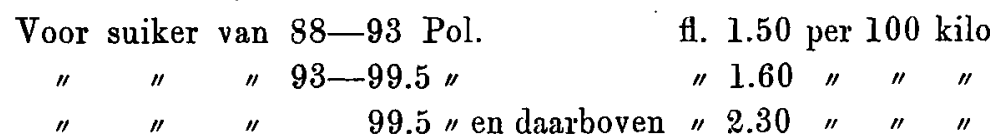

Deze premiën worden echter beperkt.door de bepaling, dat Ecun. 1895. 
het totaal der door de staatskas in een campagnejaar uit te keeren premiën niet meer mag bedragen dan 5.000.000 florijnen en het uneerdere door omslag over de fabrikanten moet worden terugbetaald. Om nu den omvang te berekenen van de premie in Oostenrijk-Hongarije moet allereerst de reeds vroeger ') toegelichte opmerking in het oog gehouden worden, dat de premie, die uit de staatskas betaald wordt enkel over den uitvoer, door de practijk van den handel noodzakelijk moet worden uitgestrekt over de geheele productie. Bij het bepalen van het aandeel van iederen fabrikant in de restitutie van het surplus der uit de staatskas uitgekeerde premiën boven de 5,000.000 florijnen, wordt dus zeer terecht het bedrag opgemaakt van de door iederen fabrikant genoten premiën, gerekend niet alleen over den uitvoer, maar over de geheele productie, en naar verhouding der aldus verkregen bedragen ieders aandeel in de restitutie bepaald. Maar ook de raffinadeurs moeten daarin deelen, want ook zij hebben premie genoten, bestaande in het verschil tusschen de premie over het geraffineerd, dat zij hebben afgeleverd (fl. 2.30 per 100 kilo, en die over de door hen ingeslagen ruwe suiker (fl. 1.60 of 1.50 per 100 kilo), die zij aan de fabrikanten moesten uitkeeren. De som dezer voor iedere raffinaderij opgemaakte verschillen wordt gevoegd bij de som der premiën door iederen fabrikant genoten, en bepaald hoeveel per florijn van het aldus verkregen gezamenlijk bedrag moet worden terugbetaald Evenveel moet dan door ieder per florijn gerestitueerd worden val de door hem genoten en als boven berekende premiën. Daar de hierop betrekking hebbende eindcijfers jaarlijks van gouvernementswege worden gepubliceerd, kan na deze toelichting berekend worden het bedrag der premie per 100 kilo suiker, door de fabrikanten werkelijk genoten in de campagne 1893-94, waarbij zal aangenomen worden, dat alle geproduceerde suiker 1.60 florijn genoot, zooals inderdaad met 93 pCt daarvan het geval was, terwijl slechts $7 \mathrm{pCt}$. tot de soort behoorde, waaraan 1.50 florijn werd toegekend; de onnauwkeurigheid hierbij begaan, is dus van geen beteekenis.

Het geheele bedrag der door de stantskas uitgekeerde uitvoer-

1) Zie blz. 849 . 
premiën bedroeg over het campagnejarar 1893-94: fl. 9.706.707, zoodat moest worden terugbetaald een bedrag van fl. 4.706.707. De som der door de fabrikanten en raffiuadeurs totaal genoten premiën bedroeg fl. 16.006.103, zoodat op iederen florijn van deze som, d. w. z. op iederen florijn genoten premie, moest worden terugbetaald fl. 0.294. Voor iederen fl. 1.60 komt dit te staan op een bedrag van fl 0.47 , zoodat per 100 kilo productio overblijft $f$. $1.60-0.47=1.13$ florijn premie.

Wat betreft de raffinadeurspremie stelt zich de berekening aldus: Aannemende dat van 100 kilo ruwe suiker 90 kilo geraffineerd vervaardigd worden, zoo geniet de raffinadeur aan premie per 100 kilo geraffineerd : $2.30-\frac{9}{10} \times 1.60=0.52$ Horijn. Voor de campagne 1893-94, moest echter per florijn worden terugbetaald fll. 0.294, dus op $f l .0 .70$ ): fl. 0.21 , zoodat per 100 kilo geraffineerd overbleef een premie van $0.52-0.21$ $=0.31$. florijn.

Deze is de zuivere berekening, waarbij de premie der raffinadeurs en die der fabrikanten van elkaar gescheiden zijn. Hierop zij vooral de aandacht gevestigd, orndat van verschillende zijden foutieve berekeningen omtrent de Oostenrijksche premiën zijn opgesteld, waartoe men komt, indien men slechts de algemeene bepalingen der wet in het oog vat, zonder die in verband te brengen met alle omstandigheden, waardoor deze worden gewijzigd.

De toestand, waarin de Oostenrijksch-Hongaarsche suikerhandel onder deze wetgeving zich bevindt, wordt uitgedrukt door de volgende cijfers:

1893-94 1894-95 millioen $\mathrm{K}^{\mathrm{o}}$. millioen $\mathrm{K}^{\circ}$.

Productie van beetsuiker

$832.1 \quad 1042.9$

Invoer beetsuiker . . . . . . . . van geen beteekenis

Invoer geraffineerde suiker . . . . . van geen beteekenis

Uitvoer van beetsuiker . . . . . . . $\quad 92.2 \quad 61.6$

Uitvoer van geraffineerde suiker . . . $\quad 358.2 \quad 351.8$

Men ziet, dat de hooge surtaxe den invoer van bijkans alle

1) $\mathrm{Bij}$ de omslagberekening voor de restitutie wordt nl., zooals boven bleek, het raffinageverlies niet in aanmerking genomen en de door de raffinadeurs genoten premie eenvoudig op 2.30 $1.60=0.70$ florijn p. 100 kilo gesteld. 
suiker uit den vreemde belet en bovendien, dat de premie der raffinadeurs deze in staat stelt tot zeer belangrijke exporten van suiker. Inderdaad beliep de hoeveelheid suiker, die als geraffineerd over de grenzen werd gebracht in 1893-94 bijna het viervoud en in 1894-95 bijna het zesvoud van den uitvoer van ruwe ruiker. Wat betreft het campagnejaar $1893-94$ Inag niet verzwegen worden, dat deze cijfers verkregen ziju onder den invloed van een syndicaat der raffinadeurs, dat sedert is outbonden, en zich ten doel stelde de prijzen van geraffineerde suiker op de biunenlandsche markt te verhoogen, door aan iedere ralfinaderij haar contingent in de levering voor de binnenlandsche consumtie an te wijzen. Inderdaad is het op deze wijze aan de Oostenrijksche raffinadeurs gedurende een drietal jareu gelukt met behulp der surtaxe de prijzen op te voereu. In IS94, dreigde het spel echter onderbroken te worden door eenige nieuw opgerichte raffiuaderijen, die niet verkozen zich bij het syndicaat aan te sluiten. De raffinadeurs vormden toen eeu auder plan, waardoor dit bezwaar moest worden overwonnen; zij zochten de beetsuikerfabrikanten te bewegen de verplichting op zich te nemen slechts aan die raffinaderijen te leveren, die zich bij het syndicaat hadden aangesloten, wardoor dus de anderen, zich verstoken ziende van grondstof, genoodzaakt zouden zijn toe te tredcn. Tegenover deze verplichting zouden de fabrikanten zich in het gennt gesteld zien van de helft der voordeeleu, die uit de prijsverhooging, welke dan tot 5 florijneu per 100 kilo geraffineerd zou worden opgevoerd, zouden voortvloeien.

Op zeer vernuftige wijze werd een systeem van winstverdeeling in elkaar gezet, dat ongeveer hierop neerkwam: men zou aannemen, dat de prijs van geraffineerd bepaald wordt door de som der volgende deelen: prijs der grondstof, raffinagekosten, gewichtsverlies, accijns en premie. Het verschil tusschen deze som en den werkelijken marktprijs zou als de winst vin het syndicaat beschouwd, en gelijkelijk verdeeld worden tusschen raffinadeuirs en fabrikanten. Bij een marktprijs van 15 florijnen voor ruwe suiker zou dus b.v. de normale prijs van 100 kilo geraffineerd zijn :

marktprijs ruw. raffinagekosten. gew. verlies $10 \mathrm{pCt}$. accijns. premie.
fl. 15.- + fl. $4.50+$
fl. $1.50+$
H. $11 .-+$ H1. 2.30
$=34.30$. Horijnen. 
Was uu de marktprijs b.v. 38 florijnen dan zou het verschi] valı 3.70 thorijnen als syndicaatswinst gelijkelijk tusschen raffinadeurs en fabrikanten verdeeld worden.

Aangelokt door de schoone voordeelen, die deze regeling ook hier beloofde, traden de beetsuikerfabrikanten toe, en cle zaak zou haar beslag gekregen hebben, indien niet een spaak in het wiel gestoken ware van wege de regeering, die weigerde hare goedkeuring te hechten aan de statuten der daartoe gevormde vereeniging. De pogingen der raffinadeurs om langs anderen weg diegenen onder hen, die weigerachtig waren, tot toetreding over te halen leden schipbreuk en omstreeks het einde van September i 894 werd het syndicaat ontbonden. Of en in hoeverre het raffinadeurs-syndicaat er in slaagde den prijs van geraffineerde suiker op de binnenlandsche markt te verhoogen, kan eenigszins worden afgeleid uit de prijzen, die te Triëst genoteerd werden voor tabletten (Würfel) transito en voor de consumtie (veraccijnsd) gedurende het bestaan van het syndicaat en daarna.

IIJDENS HE'L SYNDICAAT.

Prijzen in Horijnerı p. 100 kilo.

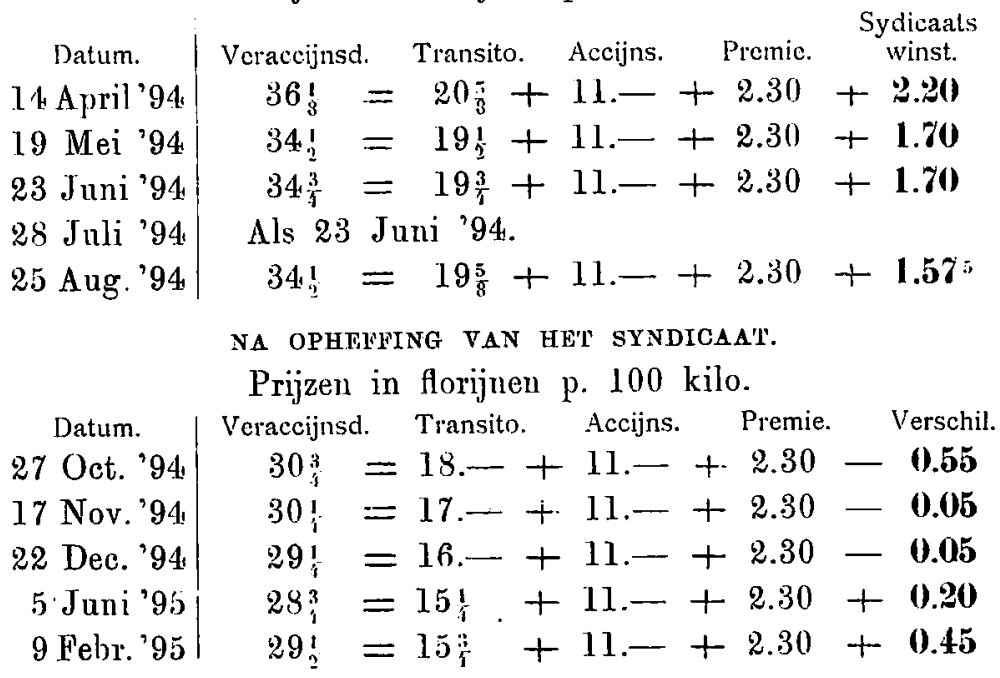

Volgrons deze cijlers zou de gemiddelde syndicantswiust gewcest ziju 1.77 florijn per 100 kilo, mar in de beide eerste jaren heeft zij wanrschijnlijk meer bedragen, zoodat de meening grond heeft, dat het syudicant, meer dan de uitvoerpremie, 
die op 0.31 florijn berekend werd, heeft bijgedragen om het Oostenrijkssche geraffineerd een eerste plaats op de Europeesche markt te verschaffen, een plaats, die het blijkens het uitvoercijfer voor 1894-95 ook thans, nadat het syndicaat gevallen is, blijft handhaven. ')

\section{DUITSCH L A N D.}

In 1Duitschland wordt op alle soorten van binnenlandsche beetsuiker een accijns geheven van 18 mark per 100 kilo Deze accijns wordt berekend naar de werkelijke productie, zoodat daarin voor de fabrikanten geen premie kan verscholen liggen. Het invoerrecht bedraagt voor alle soorten van suiker en suikerhoudende vloeistoffen 36 mark per 100 kilo, zoodat in Duitschland een surtaxe van 18 mark per 100 kilo bestaat. Bovendien genieten de fabrikanten een premie over de door hen geexporteerde suiker, die daartoe in drie klassen $a, b$, en c verdeeld wordt, als:

a. Rnwe suiker van minstens $90 \mathrm{pCt}$. suikergehalte en geraffineerde suiker van minder dan $98 \mathrm{pCt}$. maar minstens 90 pCt. suikergehalte.

b. Kandij en suiker in witte volle harde brooden, blokken, platen, stangen of tabletten, of in tegenwoordigheid der ambtenaren van den accijns gemalen; zoogenaamde kristallen en andere witte harde doorschijnende suiker in kristalvorm van minstens $99 \frac{1}{2}$ pCt. suikergehalte.

c. Alle overige harde suiker, alsmede alle witte droge suiker in kristal-, kruimel- en meelvorm van minstens 98 pCit. suikergehalte, zoover niet behoorende in klasse b.

$\mathrm{Bij}$ den uitvoer van suiker wordt betaald voor:

Klasse a een premie van 1.25 mark per 100 kilo.

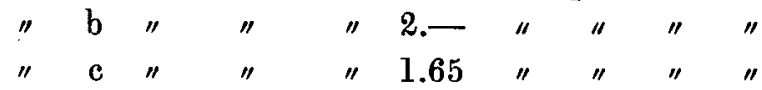

Klasse a vertegenwoordigt de ruwe suiker, alsmede de bas-

1) Als laatste bericht kan de vorming van een nieuw syndicaat der raffinadeurs in Oostenrijk gemeld worden, dat met 1 Nov. 1895 is in werking getreden, en wiens eerste claad geweest is, de verhooging van den binnenlandschen marktprijs van geraffineerd met 1 à 1.50 florijn per 100 kilo. 
terden, klasse b de geraffineerde suiker, en klasse $\mathrm{c}$ nog een rubriek, die van weinig belang is, daar haar uitvoer in 92-93 slechts 6 van de 695 millioen kilo bedroeg en dus buiten beschouwing kan blijven. Op grond hiervan kan de premie der beetsuikerfabrikanten gesteld worden op 1.25 mark per 100 kilo, die dus weder, evenals in Oostenrijk, niet alleen gemoten wordt over den uitvoer, maar over de geheele productie. Op gelijke wijze als voor Oostenrijk wordt nu ook de raffinadeurs-premie in Duitschland becijferd op $2.00-\frac{1(0)}{90}$ $\times 1.25=0.61$ mark per 100 kilo.

Onder de werking dezer wet zijn in Duitschland de volgende resultaten verkregen:

1893-94 1894-95 i) millioen ku. millioen $\mathrm{ko}$.

Bimnenlandsche productie van beetsuiker $1368.3 \quad 1831.6$ Invoer van ruwe suiker . . . . . 0 Invoer van geraffineeerde suiker . . . 0.4$\} 1.2$ Uitvoer van ruwe suiker . . . . . 4 437.- 609.7 Uitvoer van geraffineerde suiker . . . 261.- 391.7

Ook in Duitschland heeft dus de surtaxe bewerkt, dat de hoeveelheid suiker, die over de grenzen wordt ingevoerd, van green beteekenis is, terwijl daarentegen zeer belangrijke exporten te vermelden vallen, wier eijfers tegenover die van Oostenrijk echter dit verschil aanwijzen, dat terwijl de uitvoer van dit laatste land voor verreweg het grootste deel uit geraffineerd bestond, in Duitschland daarentegen de gelaffineerde tegenover de ruwe suiker sterk in de minderheid is.

Bij de wet van 31 Mei 1891, waarbij de boven omschreven regeling was ingevoerd, was bepaald, dat de premiën na $31 \mathrm{Julì}$ 1895 zouden verminderd worden resp. op 1.- mark, 1.75 mark en 1.40 mark p. 100 kilo. Intusschen is in de campagne 1894-95 de wereldproductie van beetsuiker tegenover die in 1893-94 van 4 op 5 inillioen tou gestegen en tengevolge van de daardoor uitgebrokene beruchte crisis van het jaar 1894, verkeert ook de Duitsche beetsuikerindustrie in nood. Aan het angstgeschrei der fabrikanten heeft de Duitsche regeering geen

1) De eijfers voor 1894-95 zijn gedeeltelijk nog slechts als voorloopige te beschouwen. 
weerstand kunnen bieden, en het door haar ingediende ontwerp, waarbij de vroegere premiën worden gehandhaafd tot 31 Juli 1897, dus gedurende nog twee jaren, is onlangs door den rijksdag bekrachtigd. Deze zoogenaamde suikernoodwet heeft dus slechts een voorloopig karakter en in Duitschland is men ijverig in de weer om te zoeken naar een regeling, waarbij de vermeerdering der productie niet langer, als voorheen, wordt in de hand gewerkt, maar tegengegaan, zonder dat nochtans daarbij aan de industrie alle bescherming wordt ontnomen.

\section{$\mathrm{N}_{\text {SSCHRIFT. }}$}

Juist vóór het ter perse gaau dezer bijdrage komt het bericht omtrent een bij den Duitschen bondsraad ingediend wetsontwerp, dat een regeling in den bovenbedoelden zin aanbiedt.

Het meest in het oog vallend bij deze nieuwe regeling is de verhooging der uitvoerpremiën, die voor de bovenvermelde klassen a, b en c verhoogd worden van 1.25, 2.- en 1.65 mark op resp. 4.-, 5.25 en 460 mark per 100 kilo.

Tegen het gevaar echter, dat deze premiën, die als "kamppremiën" tegen de concurrentie in het buitenland worden beschouwd, op nieuw tot belangrijke uitbreiding der productie zouden aanleiding geven, wordt gewaakt door een bedrijfsbelasting, progressief naar de mate der productie en bedragende : $1^{\circ}$. Voor fabrieken met een productie tot 500.000 kilo, 0.05 mark; van 500.000 tot 1.000 .000 kilo, 0.10 mark enz. met een verhooging van telkens 0.05 mark per 100 kilo voor iedere 500.000 kilo meerdere productie.

20. Voor dat gedeelte, warmede de productie van iedere fabriek een voor haar vastgesteld contingent, vermeerderd met 5 pCt., overtreft, 1 mark per 100 kilo.

Door deze beide bepalingen wordt dus reeds een uitbreiding der productie belemmerd, waartoe echter nog een andere matregel krachtig moet medewerken.

Vooraf zij opgemerkt, dat het totaal bedrag, waartoe de uitvoerpremie wordt uitgekeerd, beperkt wordt door de bepaling, dat dit bedrag niet mag overtreffen 25 pCt. van de opbrengst van den accijns (die, ter dekking van de verhoogde premiën, van 18 tot 24 mark per 100 kilo wordt verhoogd), vermeerderd met de opbrengst der bedrijfsbelasting. 
Vodr hetgeèn liét totale bedrng der uitvoerpremiën deze som indoht overtitieffèn, worden de fabrieken aansprakelijk gesteld, nar verhouding van haar supercontingent.

Men ziet dat ook door deze bepaling aan de productie krachtig de rem wordt aangezet, daar, zoo hare uitbreiding de overschrijding der limiet voor het bedrag der uitvoerpremiën ten gevolge heeft, de fabrikanten daarvan de lasten zullen dragen; naarmate zij hun coutigent te boveth gegaath itj en dus die uitbreidíng veroorzaakt hebben.

Hierbij zij nog opgemerkt, dat de bedrijfsbelasting, door de industrie op te brengen, weder tot de industrie terugkeert, mair thans anders over de fabrieken verdeeld.

De gezamenlijke contingenten worden voor het campagnejaar 1896—97 vastgesteld op 1400 millioen kilo en met deze som als basis het contingent voor iedere fabriek vastgesteld, naar verhouding harer productie gedurende de laatste vijf jaren. De berekening is in dier voege opgemaakt, dat bij deze productie van 14,00 millioen kilo en bij een consumtie van 600 millioen kilo de uitvoerpremiën ten naaste bij door het daarvoor beschikbaar gestelde bedrag zullen worden gedekt. Dit laatste wordt getaxeerd op 34.604.000 mark, waarvan 31.104.000 mark vertegenwoordigen $25 \mathrm{pCt}$. van de netto opbrengst van den accijns, en 3.500.000 mark de netto opbrengst der verbruiksbelasting.

Hoe kunstig deze contingenteeringsvoorstellen ook in elkâar mogen zijn gepast, de hoofdindruk van het ontwerp wordt teweeggebracht door de bepaling omtrent de belangrijke verhooging der premie. Intusschen is het ontwerp nog geen wet.

\section{B E L G I ti,}

De accijns op de suiker bedraagt in België 45 francs per 100 kilo ruwe suiker $2^{e}$ klasse, overeenkomende met Nrs. 10-15 excl. De andere soorten betalen naar rato van haar gehalte, waartoe zij in vier klassen verdeeld zijn. De beetwortelsuikerfabrikanten worden aangeslagen naar de hoeveelheid en de dichtheid van het sap en wel per 100 liters sap en per gnaad! dichtheid bij $15^{\circ} \mathrm{C}$. voor 1700 gram $\mathrm{x}$ u w c s u iker $2^{\mathrm{e}} \mathrm{kT}$ Tas e:.. Bovendien worden de fabrikanten onderworpen qap een supple- 
mentairen aanslag van 6 of 8 pCt. uilajmate zij door middel van osmose of van het scheidingsprocédé suiker vervaardigen uit de melasse, die in hunne eigene fabrieken gewonnen wordt. De afschrijving der fabrikanten bij uitvoer naar het buitenland is gelijk aan den accijns; indien echter de driemaandelijksche opbrengst van de suikerbelasting ininder bedraagt dan 1.500 .000 franç, dan wordt de basis voor de afschrijving bij uitvoer verminderd met 3 francs per 100 kilo.

De surtaxe bedraagt $15 \mathrm{pCt}$. van de sommen, voor den accijns der vier klassen vastgesteld.

Bij het Belgische stelsel is in de fabrieken geen exercice van de zijde vau den fiscus ingesteld, zoodat de premie, die in het stelsel voor den fabrikant ligt opgesloten niet nauwkeurig kan worden geconstateerd. $O p$ grond van hier en daar verspreide gegevens van officieelen aard worde het gemiddelde excedent echter anngenomeu op $20 \mathrm{pCt}$. van den aanslag. In de campagne 1893-9.1 werden de suikerfabrieken in België aangeslagen voor een productie van 188.3 millioen kilo ruwe suiker, zoodat het excedent à 20 pCt. berekend wordt op 37.7 millioen kilo: de hierover ingevorderde accijns a 45 franes per 100 kilo bedraagt 16.965.000 francs. Deze som stelt echter niet in haar geheel de premiewinst voor, daar de wet, zooals boven reeds gemeld is, bepaalt, dat zoo dikwijls de driemaandelijksche opbrengst van den accijns het bedrag van 1.500 .000 fraucs niet bereikt heeft, op den drawback bij den uitvoer 3 frnnes per 100 kilo zal worden ingehouden, zoo van de ruwe als van de geraffineerde suiker. In het jaar 1894: heeft deze korting plats gehad van $10 \mathrm{Juni}$ tot 12 December en de uitvoer van $\mathrm{ruw}$ e suiker heeft gedurende dat tijdsverloop ongeveer bedragen 117 millioen kilo. De korting bedroeg dus 3.510 .000 francs zoodat een werkelijke accijnswinst vau 13.455.000 francs overblijft. Deze orgeslagen over een productie van 226 millioen kilo geeft een premie van 5.95 franes per 100 kilo ')

1) $\mathrm{Bij}$ het vermelden van dit cijfer moet worden opgemerkt, dat uit de suikeraccijnsregeling in België de zoogenaamde «handel in rechten" ontstaan is, waarover hier niet kan worden uitgeweid, maar als de uitkomst waarvan slechts aangeteekend zij, dat een groot deel der premie, die aan de inclustrie moest ten goede komen; is overgegaan in handen der speculanten. Wèl een bewijs hoe vicieus deze wetgeving is. 
De statistische cijfers voor België waren in millioentailen kilo's :

1893-94 1894-95

Binnenlandsche productie (aanslag +20 pCt.) $226 \quad 251$

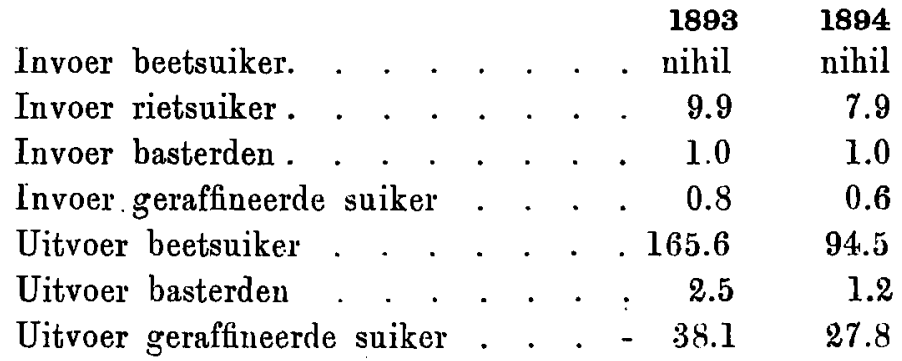

Men ziet, dat ten gevolge van de surtaxe ook in België de invoer van suiker zeer gering is; in hoofdzaak bestaat zij uit zekere hoeveelheid koloniale suiker, die in 1894, voor ongeveer een derde gedeelte (3.4 millioen kilo) uit Java werd angevoerd.

De belangrijkheid van België als suiker produceerend land valt in het oog, indien men bedenkt, dat zijn productie meer dan een derde bedraagt van die van geheel Frankrijk en dat de uitvoer van ruwe suiker dien van Frankrijk overtreft, van welken uitvoer Nederland in 1893 niet minder dan 55.6 millioen kilo voor verbruik ontving.

NASCHRIF"Y.

Sedert deze bladzijden zijn geschreven, ziju een aantal veranderingen gebracht in de hier beschreven Belgische suikerwet.

Vooreerst is de vaststelling der surtaxe, die voorheen op 15 pCt. vau den accijns bepaald was, overgelaten aan de regeering onder die restrictie, dat de grenzen van 10 en 15 pCt. van den accijns niet mogen worden overschreden. Bij Koninklijk Besluit is zij nu voorloopig vastgesteld op $10 \mathrm{pCt}$.

De aanslag der beetsuikerfabrikanten wordt, te begiunen met de campagne $1896-97$, vau 1700 op 1750 gram verhoogd. Bij toepassing van osmose of vau het scheidingsprocédé wordt deze aanslag met 5.5 pCt. resp. 7.4 pCt. verhoogd; indien buiten de eigen melasse van den fabrikant nog vreemde melasse ann deze bewerkingen wordt onderworpen, worden genoemde cijfers: 6.5 pCt. resp. 8.4 pCt.

De minimum opbrengst van den accijns en van de invoer- 
jechten wordt gebracht op 6.500.00n firatics per janr. Indret dit inidindum niet bereikt wordt, wordt het an het eind van het werkjaar o'p té thaken te kort omgeslagen over de beetsuikerfabrikanten naar verlioutding vau hun anslag. Hierdoor vervalt dus de vroegere regeling; marbij het deficit werd verhaald op den drawback bij nitvoer, eent regeling, die rich in de practijk als zeer ondoelmatig had leeren keuwer.

$B$ ij de nieuwe wet ontdekt men twee factoren, die de preinie der fabrikanten schijnbaar verminderen: de verhooging van den aanslag van 1700 tot 1750 gram en die van de mintmumopbrengst $\operatorname{van} 6.000 .000$ op 6.500 .000 francs.

$\dot{W}_{i j}$ zeggett $s c h i j n b a a r$, want in werkelijkheid zal de cerstgenoemcle verifơoging waarschijnlijk slechts dieuen om het vastgestelde minimum vaii opbrengst reeds bij eersten ainslag uabij te komen of te doen bereiken en daarmede den omslag grootendeels of geheel te doen vermijden. En de tweede verhooging verandert insgelijks van aanzien, wauneer men in aanmerking neemt dat de eigenaardige wijze, waarop het ontbrekende aan de driemaandelijksche minimnmopbrengst vroeger werd verhaald, de werkelijke jaarlijksche opbrengst van den accijns bracht: in 1890 op 6.482 .000 francs; in 1892 op 6.305.000 francs; en in 1894, op.6.502.000 francs, dus ontgeveer 500.000 franes hooger dan het toen vastgestelde minimum. Bovendien is thans bepaald, dat het eventueele surplus van eenig jaar boven het minimum, op de opbrengst van het volgende jaar kan worden overgeschreven.

De minister heeft dan ook uitdrukkelijk verklaard, dlat ann de wet geen verkorting der voordeelen van de fabrikanteu ten grondslag ligt; en hare strekking moet veeleer gezocht worden in de oplossing der huishoudelijke bezwaren, die zich in de Belgische suikerindustrie bij de oude regeling voordeden.

\section{R U S L A N D.}

Het land, dat thans aan de beurt ligt, is alle aanilacht waardig, wegens de eigenaardige wijze, waarop de inclustrie, sedert de afschaffing der open nitvoerpremiën in 1856 aan zich zelf overgelaten, met behulp eener hoog opgevoerde surtaxe toestanden heeft in het leven geroepen, waarbij zij zich zeer belangrijke voordeelen ziet in den schoot geworpen. 
De suikerwetgeving in Rusland is zeer eenvoudig; zij bestaat uit een accijns op alle soorten van binuenlandsche suiker ten bedrage van 1 roebel 75 copeken per pud of 13.57 gulden per 100 kilo '). Deze accijns wordt geheven naar de werkelijke productie en bij uitvoer naar het buitenland terugbetaald, zonder dat hierin eenige premie verscholen ligt. Het invoerrecht bedraagt 3 gouden roebels per pud voor ruwe suiker en 4 gouden roebels per pud voor geraffineerde suiker (resp. 34.80 en 46.40 gulden per 100 kilo) ${ }^{2}$ ), waaruit een surtaxe berekend wordt van 2123 gulden per 100 kilo voor ruwe en 32.83 gulden per 100 kilo voor geraffineerde suiker. Met behulp van deze hooge surtaxen, die heu tegeu de buitenlandsche concurrenten beschermden, hebben de Russische fabrikauten getracht door het vormen van eell syudicaat den suikerprijs op de binnenlandsche markt op te voeren. Dit syndicaat werd gevormd toen, tengevolge van de crisis van 1854-85 groote voorraden onverkochte suiker in de Russische depôts waren overgebleven, zonder dat het uitzicht bestond deze voorraden an de buitenlandsche markt te quitteeren en zonder dat de regeering te bewegen was tot het verleenen van vernieuwde bescherming in den vorm van uitvoerpremiën. De fabrikanten verbonden zich toen om een bepaald gedeelte van hun productie uit te voeren, ten einde het overvoeren van de binnenlandsche markt te beletten en daardoor in staat te zijn den prijs aldaar tot zoodanige hoogte te brengen, dat niet alleen het verlies, door den uitvoer opgeleverd, zou worden gedekt, maar bovendien nog ruime voordeelen overbleven. Hoofdzaak moest bij een dergelijke overeenkomst natuurlijk zijn, de zekerheid dat de ledeu vau het syndicant hun verplichting tot uitvoer van het bepaalde quantum zouden nakomen, en om daarvoor te waken en te beschikken over alle verdere angelegenheden werd eene commissie van 25 leden aan het hoofd van het syudicaat gesteld.

Toen in 1887 het syndicaat tot staud kwam waren van de 219 suikerfabrieken 171 toegetreden; aan het einde van het tweede jaar was dit getal tot 190 en in 1891 tot 201 ge-

1) 1 papieren roebel is hierbij angenomen tot den koers van 1.27 gulden. 1 pud $=16.38$ kilo.

2) 1 gouden roebel is hierbij angenomen tot den koers van 1.90 gulden. 
klommen; bij de hernieuwing van het syndicaat in 1894 had het 212 van de toen bestaande 227 fabrieken in zich opgenomen.

In verband met de productie in de laatste vijf jaren en met de hoeveelheid suiker, die voor de binnenlandsche consumtie wordt berekend, wordt voor iedere fabriek de hoeveelheid suiker vastgesteld, die zij zal moeten exporteeren. De bewijzen, dat de fabrikanten aan hunne verplichting te dien opzichte hebben voldaan, snoeten, geveritieerd door de rijksambtenaren, aan het comité van het syndiciat worden overgelegd, waarbij de handel zich van zeer eigenaardige middelen heeft weten te bedienen. Aan het syndicaatsbestuur is het uamelijk volkomen onverschillig, of de fabrikanten de door hen uit te voeren suiker leveren van hun eigen fabrikaat, of van dat eener andere fabriek, mits slechts ieder zijn bepaald aandeel over de grenzen zet en daarmede let overtollige uit het land wordt verwijderd. $\mathrm{Na}$ is het voor vele fabrieken, die ver van de havenplaatsen verwijderd liggen, voordeeliger, in plaats van haar eigen suiker te exporteeren, die te koopen van de exporteurs in een der havenplaatsen, b. v. Odessa, die hunnerzijds de suiker betrokken hebben van nabijliggende fabrieken. De exporteurs kunnen de suiker afschepen b. v. naar Londen, waarvan dan een verklaring wordt opgemaakt, onderteekend door de rijksambtenaren. Deze verklaring kan naar den fabrikant gezonden worden, voor wiens rekening de transactie heeft plaats gehad; de fabrikant zendt haar op naar het syndicaatscomité en heeft daarmede aan zijn verplichting voldaan, zoodat hij de vrijheid heeft zijn geheele eigen productie in het binnenland af te zetten.

De geheele transactie kan echter langs een nog eenvoudiger weg plaats hebben. Het is namelijk voldoende, dat de exporteur koopt en exporteert, van al de aldus uitgevoerde partijen certificaten laat opstellen en deze verkrijgbaar stelt voor de fabrikanten, die zich hiervan kunnen bedienen bij het syndicaatscomité, ter afschrijving op bun verplichten uitvoer. Inderdaad .geschieden de zaken langs dezen weg en bestaat er een levendige handel in deze certificaten van uitvoer, waarvan de prijs uitdrukt het verschil tusschen den marktprijs der suiker in de Russische havens (Odessa) en dieu te Londen, vermeerderd met het bedrag van de transportkosten naar Londeu of 
andere plants van besternming, en van audere onkosten an het transport en den verkoop verbondeu.

Men kan den koers dezer certiticateu als inatstaf gebruiken voor de premie der Russische fabrikanten. Deze premie toch bestaat eveneens in het prijsverschil van de suiker in de Russische havens en te Londen, warbij wordt uitgegaan van de veronderstelling, dat, indien geen surtaxe bestond, het buitenland tot denzelfden prijs zisu kunnen leveren in die Russische havens als te Londen, tegen welke onderstelling o. i. geen bezwar bestaat. Indien men dus van den koers der certificaten in mindering breugt den vracthtprijs, zeg Odessa--Londen, plus verdere onkosten, dan komt men tot het bedrag der premie. De koers der uitvoercertificaten was :

$$
\begin{aligned}
& 30 \text { Oct. } 94=1.40 \text { roebel } \\
& 3 \text { Dec. '94 }=1.54 \text { roebel } \\
& 5 \text { Nov. " }=1.415 \text { " } \\
& 11 " \text { " }=1.585 " \\
& 12 " \text { " } 12=1.40 \text { " } \\
& 23 " \text { " }=1.66 \text { ", } \\
& 20 " \text { " }=1.425 " \\
& 16 " \text { " }=1.50 \text { " }
\end{aligned}
$$

gemiddeld dus 1.49 roebel per pud. Neemt men den gemiddelden vrachtprïjs Odessa-London (resp. Odessa-Smyrna, -Constantinopel, -Genua, - $\Lambda$ msterdain enz.) met de onkosten aan op 0.20 roebel per pud, dan heeft over dit tijdsverloop de gemiddelde premie bedragen $1.49-0.20=1.29$ roebel. Deze berekening geldt voor witte zandsuiker (p. m. 99, polarisatie).

Ter contrôle dezer uitkomst kan ook de volgende weg ingeslagen worden: Gedurende de maanden Nov.-Dec. 1894 was de middemprijs van witte zandsuiker voor binnenlandsche levering 4.65 roebel per pud, dat is, na aftrek van 1.75 roebel voor den accijns, 2.90 roebel. De iniddenprijs te Londen was gedurende hetzelfde tijdsverloop voor suiker van 88 pCt. : 9 shilling per centweight van 50.8 kilo, dat is voor suiker van 99! pCt. (witte Russische zandsuiker) $10 \mathrm{sh}$. 6 per centweight. De roebelkoers was in dien tijd: 100 shillings $=48$ roebels, dus 10 sh. $6=5.04$ roebels, zoodat voor den wereldmarktprijs van witte Russische zandsuiker, in roebels per pud uitgedrukt, wordt gevonden : $5.04 \times \frac{16.38}{50.8}=1.62$ roebel, een verschil dus van 1.28 roebel met deu prijs te Odessa. Dit versehil, de premie 
voorstellende, komt overeen met het bovengevonden bedrag van 1.29 roebel.

Dit eijfer stelt dus voor de premie per pud suiker in het binuenland geleverd; het geheele bedrag dier premie in 1893-94, toen het binnenlandsche debiet 28.7 millioen pud beliep, was dus $28.7 \times 1.29=37$ nillioen roebels of $37 \times 1.27=4.7$ millioen gulden; d. i. over de geheele productie in dat jaar van 583 millioen-kilo $\mathbf{8 . 0 6}$ gulden per 100 kilo.

Aan de te hooge stijging ler suikerprijzen door den invloed van het syudicaat heeft de Russische wetgever perk gesteld door aall de regeering het recht toe te kennen om, indien de prijzen te Petersburg tot $6 .-$ a 6.60 of te Odessa tot 5.50 à 6.- roebels stijgen, het inkonende recht der ruwe suiker met de helft te verminderen. Toen dit geval zich in 1892 voordeed en de prijs te Odessa wegens geringen suikervoorraad en slechte oogstvooruitzichteu tot 5.70 roebels was gestegen, aarzelde de regeering echter om van de haar verleende bevoegdheid gebruik te maken, vreezende daardoor de sluisdeuren te ver te openen, en het land door de in het buitenland overvloedig voorhanden voorraden te doen overstroomen, tot blijvende schade wellicht voor de industrie en tot storing in ieder geval van de economische verhoudingen. Daarom koos de regeering een anderen weg, waardoor de suiker toegang verkreeg, zouder dat overvoering der markt $t=$ duchten was. Het gouvernement ontbood voor eigen rekening suiker uit het buitenland en stelde deze verkrijgbaar tegen vaste prijzen (5.23 roebels te Kiew), wanrdoor de verdere stijging der prijzen belet werd. De financieele resultaten dezer transactie zijn later door het ininisterie van financiën bekend gemaakt en worden hier medegedeeld, omdat ook deze het licht werpen op de mate van bescherming die de Russische industrie langs den boven angewezen weg geniet.

Werden aangekocht 1.714.018 pud suiker, waarvoor incl. accijns, transport en commissie betaald werd 6.225.068 roebels, d. i. p. pud 3.63 roebels. Van deze geimporteerde suiker werden 1.697.077 pud voor 9.436.561 roebels op de binnenlandsche markt verkocht, dat is voor 5.56 roebels p. pud. dus met een winst van 1.93 roebels p. pud. De totale winst voor het you- 
vernement, excl. die over het onverkochte gedeelte was dus 3.275.358 roebels. Met het oog op deze resultaten behoeft men dus niet in twijfel te trekken de hooge premiecijfers, die boven werden berekend. Immers het winstcijfer van 1.93 roebel p. pud stelt weer het bedrag voor, waarmede de binnenlandsche marktprijs den buitenlandschen overtreft, en mag dit resultaat niet voor het boven gevondene van 1.29 roebel gesubstitueerd worden, het is omdat men hier te doen heeft met buitengewone omstandigheden, waardoor de prijsverhouding in het buitenen binnenland niet normaal was.

Zooals boven reeds vermeld is, werd in 1894 het Russische syndicaat hernieuwd, waarbij van de 227 bestaande fabrieken 212 toetraden. Nochtans verkeert op dit oogenblik het syudicaat, in precairen toestand. Wegens den zeer lagen suikerprijs op de buitenlandsche markt, waren in den laatsten tijd aan den uitvoer bijzonder hooge verliezen verbonden. Verschillende leden van het syndicaat zijn dientengevolge hun verplichtingen met betrekking tot den uitvoer niet nagekomen. $\mathrm{B} \ddot{j}$ het proces dat nu deswegens door het sijndicaat gevoerd wordt tegen Mevrouw $O$. Baskakow treedt de quaestie der rechtsgeldigheid van het syndicaat op den voorgrond, die bij de uitspraak der rechtbank in eerste instantie niet erkend is. Van deze uitspraak is appèl aangeteekend; maar mocht ten slotte de vordering niet worden toegewezen, dan zallen de dagen van het syndicaat, dat sedert 1884 den toestand in Rusland geheel beheerscht heeft, geteld zijn. Mocht dit komen te vallen, dan verwacht men, dat de staat zich met de regeling der zakeu, hetzij door contingenteering der productie of langs anderen weg zal inlaten.

De volgende cijfers geven een overzicht van de productie, de consumtie en den uitroer van suiker in Rusland.

1893-94 1894-95 millioen $\mathrm{K}^{\circ}$. millioen $\mathrm{K}^{*}$.

Productie van beetsuiker. . . . . $583 \quad 532$

Invoer van suiker . . . . . . . nihil nihil

Debiet van suiker in het binnenland $474.1 \quad 4,43.2$

Uitvoer van suiker naar Europa. . . $\quad 56.6 \quad 56.2$

Uitvoer van suiker naar Azië . . . $\quad 23.0 \quad 28.0$

ECON. 1895. 


\section{NASCHRIF'I.}

De gebeurtenissen in den suikerhandel volgen elkander in dezen tijd snel op. Sedert de samenstelling van dit hoofdstuk is voor Rusland een geheel andere toestand in het leven geroepen door het krachtcladig ingrijpen der Russische regeering in de aangelegenheden der industrie. Door een Keizerlijke Ukase is de quaestie der contingenteering, waarover vooral in Duitschland en Oostenrijk reeds zooveel is gesproken en geschreven, voor Rusland plotseling tot een oplossing, althans tot een decisie gebracht.

Voortaan zal voor iedere fabriek een norm worden opgemaakt, gebaseerd op de binnenlandsche consumtie der laatste drie jaren. Deze norm zal voorstellen het aandeel, dat jedere fabriek toekomt, in de leveringen voor het binnenland. Wat daarboven geproduceerd wordt, wordt belast met den dubbelen accijns, die slechts bij uitvoer over het volle bedrag wordt terugbetaald.

De fabrikanten zijn dus genoodzaakt hun supercontingent uit te voeren, daar het voor de binnenlandsche consumtie te zwaar is belast, en in zooverre heeft het gouvernement de taak van het syndicaat, zij het onder anderen vorm, overgenomen.

Hoe hoog in het vervolg de Russische premie zal zijn, m.a.w. tot hoe hoog men in Rusland bij dezen nieuwen staat van zaken den suikerprijs zal kunnen opvoeren moet de toekomst leeren.

Voor de totale jaarlijksche consumtie is aangenomen 27 millioen pud en daarbij voegt de wet 5 millioen, die als reserve in het land moeten blijven om plotselinge prijsverhooging, tengevolge van eventualiteiten, tegen te gaan. Wanneer de prijs van kristalsuiker in het district Kiew gedurende twee weken in de periode 1 Sept. 1895 tot 1 Jan. 1896 tot 4.75 roebels, en in die van 1 Januari tot 1 Sept. 1896 tot 5 roebels per pud gestegen is, kan uit den reservevoorraad suiker in de consumtie gebracht worden. Bij dit. alles schijnt de Russische regeering nog maatregelen te willen nemen tot het tegengaan der oprichting van nieuwe fabrieken en der vermeerdering van het kapitaal der oude. Iedere week brengt nieuwe berichten omtrent de plannen der regeering ten opzichte der suikerwetgeving.

Wat onder deze omstandigheden het lot van het syndicaat zal worden is nog niet met zekerheid te zeggen.

\section{Z W E D N.}

In Zweden worden de beetsuikerfabrikanten aangeslagen aar de hoeveelheid verwerkte beetwortels in dier voege, dat 
het wettelijk aangenomen rendement aan witte suiker bedraagt 8.25 pCt. van het gewicht der beetwortels '), en dat voor de aldus vastgestelde hoeveelheid suiker an accijns betaald wordt 11.75 kronen p. 100. kilo. De inkomende rechten bedragen: voor geraffineerde suiker en ruwe suiker $\mathrm{N}^{\circ}$. 18 en daarboven 33 kronen p. 100 kilo, voor ruwe suiker beneden $N^{\circ} 18$ 23.50 kronen p. 100 kilo en voor melasse 10 kronen per 100 kilo. Voor suiker beneden $\mathrm{N}^{\mathrm{o}} \cdot 18$ is dus de surtaxe 23.50 $11.75=11.75$ kronen p. 100 kilo, dat is juist het bedrag van den accijns.

Bij deze regeling steekt in de eerste plaats een accijnswinst in het wettelijk aangenomen rendement. Deze accijnswinst was, blijkens de noot onder aan deze bladzijde vroeger veel hooger dan thans, maar komt niettemin ook nu nog zeer in aanmerking. In $\mathrm{Zweden}$ is het werkelijk rendement aan suiker niet ongunstig en, mag dit op grond van de resultaten in de campagne 1892 -'93 gemiddeld op $10.8 \mathrm{pCt}$. witte suiker aangenomen worden, dan laat zich daaruit de volgende berekening opmaken :

op 100 kilo bieten 10.8 kilo suiker, waarover de accijns a

11.75 kronen per 100 kilo door de fabrikanten te vorderen, bedraagt . . . . . . . . . . . . . . $1.27 \mathrm{Kr}$.

op 100 kilo bieten 8.25 kilo suiker wettelijk aan-

genomen rendement, waarvoor den fabrikanten aan accijns à 11.75 kronen p. 100 kilo wordt berekend 0.97 "

$\begin{array}{rlll}\text { accijnswinst op } 10.8 \mathrm{kilo} & 0.30 \mathrm{Kr} \\ \text { accijnswinst op } 100 \mathrm{kilo} & 2.78 \mathrm{\prime \prime}\end{array}$

Deze waarde is berekend op witte suiker; zij wordt dus (weder aannemende de verhouding 88:100) 2.45 kronen p. 100 kilo ruwe suiker.

Daar Zweden tot nog toe behoort tot die landen, waar de binnenlandsche productie van suiker niet ten volle voorziet in de consumtie, waar dus geen overproductie bestaat, die moet worden uitgevoerd, maar integendeel suiker van uit den vreemde

1) Vobr 1 Juli 1893 was het wettelijk aangenomen rendement 6.25 pCt.: voor het tijdperk 1 Juli '93-1 Sept. '94 werd het vastgesteld op 7.5 pCt., voor 1 Sept. '94-1 Sept. '95 op 8.25 pCt. en $\operatorname{van}$ af 1 Sept. '95 voor vast op $9 \mathrm{pCt}$. 
wordt geimporteerd, zoo is het, overeenkomstig hetgeen hier reeds herhaalde malen dienaangaande is opgemerkt, waarschijnlijk, dat de suikerfabrikanten het volle invoerrecht boven den wereldmarktprijs van de suiker kunnen bedingen, en dus het volle bedrag van de surtaxe als premie genieten.

$\mathrm{Nu}$ was in de maand April 1895 de wereldmarktprijs voor beetsuiker van $8 \mathrm{~s}$ pCt. gemiddeld 11 gulden of 16.66 kronen per 100 kilo en voor geraffineerd (gemalen melis) 14.70 gulden $=22.27$ kronen p. 100 kilo ${ }^{1}$ ). Is de bovenstaande onderstelling dus juist, dan moet in die maand de middenprijs op de Zweedsche markt ongeveer geweest zijn voor ruwe suiker: 16.66 -t $23.50=40.16$ kronen en voor geraffineerde suiker $22.27+33 .-=55.27$ kronen p. 100 kilo. Volgens de daaromtrent geconsulteerde Zweedsche handelsbladen, werden in dezelfde maand April te Stokholm de volgende prijzen voor suiker genoteerd p. 100 kilo:

Malmö en Ystad raffinade. . . . . . . 55 à $56 \frac{1}{2} \mathrm{Kr}$. Helsingborger en finkross . . . . . . . $56 !$ a $57 \frac{1}{2}$ " Malmö, Ystad en Helsingborger beetsuiker 55! a 56 "

Ook de laatste soort is kennelijk consumtiewaar, gelijkstaande met geraffineerd, zoodat voor deze soorten de veronderstelling als juist mag worden aangenomen. Voor ruwe suiker stonden geen prijsopgaven ter beschikking, maar er bestaat geen grond om het verkregen resultaat voor geraffineerd ook niet voor ruwe suiker aan te nemen. Derhalve genieten de suikerfabrikanten inderdaad het volle bedrag van de surtaxe als premie en kan het totale bedrag van deze worden gesteld op:

accijnswinst. surtaxcwinst.

$2.45+11.75=14.20$ kromen p. 100 kilo ${ }^{2}$ )

Zooals dit premiecijfer aanwijst hebben de Zweedsche fabrikanten dus onder zeer aangename omstandigheden gewerkt, maar het is te betwijfelen of deze toestand nog langen tijd

1) De kroon gerekend op 0.66 gulden.

2) Dit is een minimumcijfer, daar de fabrikanten over het gedeelte, dat zij als consumtiesuiker in den handel brengen, door de hooge surtaxe op geraffineerd $33-23.50=9.50$ kronen meer maken. Hoeveel dat gedeelte bedraagt is niet bekend, zoodat dit niet in rekening kan worden gebracht. 
zal duren. De goede winsten met de beetwortelsuikerindustrie behaald, hebben aanleiding gegeven tot een enorme uitbreiding der productie gedurende de beide laatste jaren, in die mate, dat de productie, die in het campagnejaar 1892-93 nog slechts 30 millioen kilo bedroeg, voor de campagne 1894-95 op niet minder dan 70 millioen kilo geraamd is. $\mathrm{Bij}$ dergelijken voortgang is het te voorzien, dat weldra een restant ten uitvoer zal overblijven, dat de prijzen op de binnenlandsche uarkt zullen dalen, om allengs den wereldmarktprijs te bereiken. Reeds hebben de fabrikanten de hoofden bijeen gestoken om te trachten de aanstaande overproductie voor gemeenschappelijke rekening te exporteeren en onderling den prijs voor de binnenlandsche markt vast te stellen. Deze poging is echter mislukt, daar sommige fabrikanten met het oog op het verlies bij den uitvoer te lijden, hebben geweigerd toe te treden. Het zal belangrijk zijn den verderen loop van zaken in $\mathrm{Zweden}$, dat zich in de periode der kentering bevindt, na te gaan, te zien welke pogingen zullen worden aangewend om de productie tot stann te breugen, en hoe, mocht dit niet gelukken, het geheele kaartenhuis zal instorten.

De volgende cijfers geven een overzicht van den toestand van Zweden's suikerhandel:

Beetsuikerproductie 1893-94 in ruwe suiker: 43.2 mill. kilo. Invoer van ruwe suiker in 1893: 26.6 millioen kilo. Invoer van geraffineerde suiker: onbekend, gering. Uitvoer van suiker . . . . : nihil.

\section{E N E A R K E N.}

De accijns op de beetsuiker wordt in Denemarken geheven naar de werkelijke productie, een wijze van heffing, die op zich zelf geen aanleiding geeft tot eenige premie. Alleen schijut de vergoeding van den accijns bij uitvoer, die gesteld is op 3 ore per pond voor suiker boven $n^{\circ} 18$, d. i. iets hooger dan de accijns (zie beneden), zekere vitvoerpremie mede te brengen, die echter van slechts zeer geringe beteekenis kan zijn, daar die geheele vergoeding, in het jaar 1893 slechts 
11729 kronen ') bedroeg en dus hier buiten beschouwing mag blijven.

De eigenlijke bescherming der suikerindustrie in Denemarken bestaat in een surtaxe, met welks bedrag de prijs der suiker op de binnnenlandsche markt wordt verhoogd, zooals straks zal worden aangetoond. Want hoewel Denemarken zekere quantiteiten suiker exporteert, worden tevens belangrijke hoeveelheden het land voor verbruik ingevoerd, onder welke omstandigheden de industrie zeer wel in staat kan zijn de bedoelde prijsverhooging door te voeren.

Voor den accijns op het binnenlandsch fabrikaat wordt betaald :

a. Voor suiker overeenkomende met $\mathrm{n}^{0} 19$ of lichter: 2.57 ore per pond $=3.39$ gulden per 100 kilo. ${ }^{2}$ )

b. Voor suiker, die donkerker is dan $\mathrm{n}^{0} 19: 2.25$ ore per pond $=2.97$ gulden per 100 kilo.

Het tarief voor de invoerrechten luidt als volgt:

a. Kandij, suiker in brooden etc. benevens witte poedersuiker boven $\mathrm{n}^{0} 18: 6$ ore per pond $=7.92$ gulden per 100 kilo.

b. Poedersuiker (lichter dan $n^{0} 9$ ): 3 ore per pond $=$ 3.96 gulden per 100 kilo.

c. Andere poedersuiker (niet lichter dan $\mathrm{n}^{0} 9$ ), opgeloste en andere vloeibare suiker, witte stroopen, etc. 2 ore per pond $=2.64$ gulden per 100 kilo.

Wanneer men het tarief voor den accijns op het binuenlandsche fabrikaat vergelijkt unet dat voor den invoer, dan valt in het oog het belangrijke verschil tusschen de surtaxen op de hoogere en lagere soorten, zoodat voor de hoogere een aanmerkelijke surtaxewinst bestaat, die voor de lagere slechts gering is. Bij deze regeling is het niet wel anders denkbaar, dan dat de beetsuikerfabrikanten zich zoo veel mogelijk toeleggen op de vervaardiging van blanke consumtiewaar, waardoor zij het voordeel trekken van de bepalingen der wet, dat anders uitsluitend ten bate der raffinadeurs komt.

1) Hoe dit cijfer te rijmen is met de na te noemen uitvoercijfers kan hier niet verklaard worden ; overigens zijn alle hier aangehaalde getallen direct ontleend aan de officieele Deensche statistieken.

2) 1 ore $={ }_{10}^{1}$ kroun $=0.66$ cent. 1 Deensch pond $=\frac{1}{2}$ kilo. 
Wordt in de werkelijkheid an deze veronderstelling beantwoord? In de handelsberichten vau Kopenhagen wordt melding gemaakt vau drie soorten Deensche beetsuiker, met, name: "Deensche poedersuiker, Deensche ruwe suiker $n^{\circ} l$ en Deensche ruwe suiker $n^{0}$ 2." Aan een bevoegd handelscollege in Kopenhagen werd om inlichting gevraagd omtrent de qualiteit door deze benamingen voorgesteld, waarop ten antwoord werd ontvangen: "Deensche poedersuiker is een beetsuiker van "de kleur omstreeks $\mathrm{n}^{0} 19$ en polariseerende ongeveer $97 \mathrm{pCt}$. "vervaardigd ter consumtie. Deensche ruwe suiker $\mathrm{n}^{0} 1$ en 2 is een dergelijke soort van iets lagere polarisatie."

De Deensche poedersuiker is dus in ieder geval consumtiesuiker; omtrent de beide andere soorten blijft men in het onzekere. Bij de anname echter dat zij dooreen consumtiesoorten voorstellen, die slechts tegen het tarief van 6 ore $p$. pond kunnen worden ingevoerd zou de surtaxewinst bedragen 6 -2.25 $=3.75$ ore per pond of 4.95 gulden per 100 kilo. ')

In hoeverre wordt dit resultaat nu bevestigd door de prijzen op de Deensche markt? Met behulp van een uitvoerig jaarverslag omtrent den handel van Kopenhagen zijn de middenprijzeu gedurende de jarey 1893 en 1894, voor de drie soorten opgemaakt:

Deensche poedersuiker. Deenseh ruw $n^{01} 1$. Deensch ruw $n^{0} 2$.

$\begin{array}{cccccc}18931894 & 1893 & 1894 & 1895 & 1894 . \\ \text { ore per pond. } & \text { ore per pond. } & \text { ore per pond. } \\ 19 .- & 16 .- & 18 .- & 15 .- & 17 .- & 14 .-\end{array}$

Als gemiddelden prijs dezer producten worde dus aangenomen in 1893: 18 en in 1894: 15 ore per pond. Voor dergelijke waar (beetsuiker vau hoog gehalte) was de middenprijs op de Londensche markt in 1893 ongeveer: 16. sh 3 en in 1894: 12 sh. 6 per cwt. Deze eijfers geveu dus het volgende resultaat omtrent den prijs van Deensche suiker op de binnenlandsche markt, vergeleken met den wereldmarktprijs eener zelfde soort:

$$
1893 \quad 1894
$$

Prijs Deensche suiker te Kopenhagen $23.76 \quad 19.80$ gid. per 100 kilo.

Wereldmarktprijs . . . . . . $\cdot \frac{19.50}{4.26} 4 .-n n$ gld. per 100 kilo.
Verschil, resp. surtaxewinst

1) Daar blijkens de na te noemen productiecijfers beetsuiker $\mathrm{n}^{\circ} 19$ en daarboven slechts zeer weinig geproduceerd wordt, heeft men met het tarief van 2.57 ore p. pond geen rekening te honden. 
Bedenkt men, dat behalve deze hooge suikers, die in Denemarken door den aard der wetgeving bij voorkeur worden vervaardigd, noodzakelijk ook lagere moeten vallen, waarop slechts weinig surtaxewinst genoten wordt, dan schijnt het gerechtvaardigd de geheele surtaxewinst der beetsuiker-fabrikanten in Denemarken gemiddeld globaal te stellen op 4 gulden per 100 kilo productie, welk bedrag hier, echter onder bijzondere restrictie, wordt aangenomen.

Ten einde, hetgeen de toestand in Denemarken aan duidelijkheid te wenschen overlaat zooveel mogelijk toe te lichten, worden hier de statistische cijfers eenigzins uitvoeriger dan voor de andere landen opgegeven:

1892.1893.

Millioen $\mathrm{K}^{\circ}$. Millioen $\mathrm{K}^{\circ}$.

Binnenl. productie v. beetsuiker volg. rubriek a $\quad \begin{array}{lll}1.0 & 0.8\end{array}$

Binnenl. productie v. beetsuiker volg. rubriek b $18.5 \quad 26.4$

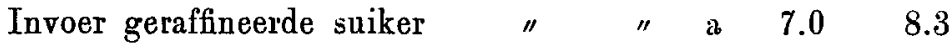

$\begin{array}{llllll}\text { Invoer ruwe suiker " } & \text { " b } & 25.6 & 15.8\end{array}$

Invoer ruwe suiker " " c $\quad 0.1$

Uitvoer geraffineerde suiker " " a 1.2

Uitvoer ruwe suiker " " b 1.8

Uitvoer ruwe suiker " " c nilil.

Van dezen uitvoer was binnenl. suiker $\quad 1.6$

" " " vreemde suiker 1.4

Uit deze cijfers blijkt, dat van de binnenlandsche beetsuiker een klein gedeelte wordt uitgevoerd, terwijl de hoofdmassa in het land verbruikt wordt. Bovendien wordt in de binnenlandsche consumtie voorzien door vrij belangrijke invoeren, zoowel van geraffineerde als ruwe suiker. Deze invoeren geschieden hoofdzakelijk uit Duitschland via Hamburg Stettin en Dantzig, wat de beetsuiker betreft, en wat aangaat de rietsuiker uit St. Croix, Demerara en Porto Rico, voor een gedeelte direct, grootendeels echter via Engeland. Opmerking verdient nog dat van den oogst van 1894 der Deensche kolonie St. Croix, die 14! millioen kilo bedroeg, Denemarken slechts 1.2 millioen kilo ontving, een verhouding, welke eenigzins herinnert aan die tusschen Java en het moederland. 
In Spanje worden voor de belasting drie soorten van suiker ouderscheiden naar gelang van de herkomst:

$1^{\circ}$. Binuenslands vervaardigde suiker, belast met 20 peseta's ') per 100 kilo.

$2^{\circ}$. Suiker uit de Spaansche koloniën, belast, met 33.50 peseta's per 100 kilo.

$3^{0}$. Vreemde suiker, belast met 50 peseta's per 100 kilo.

Aan het gouvernement is echter het recht gegeven om met de fabrikanten van beetsuiker een abonnement af te sluiten, waarbij de opbrengst van den accijns in é́n te voren vastgestelde som te verrekenen is, en warbij aangenomen wordt dat 1 hectare oplevert 25000 kilo beetwortels met een rendement van 5 pCt. ${ }^{2}$ ). Zulk een abonnement werd afgesloten met de 10 beetworteIsuikerfabrieken in de provincie Grenada, die zich tot een syndicaat hebben vereenigd. Bij dit abonnement werd bepaald, dat gedurende vier jaren een jaarlijksch bedrag vall 350.000 peseta's door het syndicaat zou worden betaald ter afdoening van den accijns. Gedurende den loop van dit abonnement nam echter de productie in die mate toe, dat deze in de campagne 93-94 tot een bedrag van 12.000.000 kilo suiker was gestegen, waarover dus bij aanslag naar de werkelijke productie had moeten betaald worden een som van 2.400.000 peseta's. De Minister van Financiën achtte het belang van 's rijks schatkist hierdoor in die mate benadeeld, dat hij vóór het verstrijken van den termijn van vier jaren het abonnement wilde verhoogen tot 1.350 .000 peseta's. Een storna van verontwaardiging brak daarop los onder de fabrikanten, die de regeering van contractbreuk beschuldigden en dreigden met de sluiting liunner fabrieken, die bij dezen stand van zaken toch haar wissen ondergang tegemoet gingen. Het einde van de dientengevolge met den nieuw opgetreden Minister van Financiën gevoerde onderhandelingen, was een verhooging

1) 1 peseta $=0.40$ gulden.

2) Hierbij zij opgemerkt, dat volgens de opgaven de werkelijke opbrengst aan suiker der drie producten in Spanje niet meer dan 6 pCt. der beetwortels bedraagt! 
varl liet abounement tot slechts 400.000 peseta's, zoorlat onder deze onstaildigheden in werkelijkheid de belastirng bedraagt

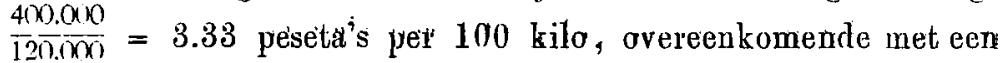
accijnswinst van $20-3.33=16.67$ peseta's per $100 \mathrm{kilo}$ prìoductie.

Behalve de 10 fabrieken, waarvan hier sprake was, bestan toog vier andere, wier gezamenlijke productie wag gesteld wordeth dis 3.000 .000 kilo suiker. Welke accijnsregeling net deze is getroffen, kath hier niet worden vermeld, maar de veronderstelling is wellicht gewettigd dat de fabrikanten wèl zulleu gezorgd hebben, niet te zeer te worden ten achtergesteld bij hun Grenadasche collega's. Derhalve worde aangenomen, dat de boven berekende accijnswinst ook voor hen geldt, waardoor een te minder grtoote fout kan begaan worden, daar hunne productie slechts één vierde van die der syndicaatsfabrieken bedraagt.

Daar Spanje geen exportland voor suiker is, is te verwachten dat ook in dit land de fabrikanten behalve den accijnswinst nog het volle genot hebben van de surtaxe. In hoever dit werkelijk het geval is, noet weer getoetst worden aau de prijzen op de binnenlaudsche markt. De prijs van binuenlandsch blank $n^{0} 1$ bedroeg in Spanje gedurende Maart 1594:96 peseta's per 100 kilo; de soort stelt consumtiewaar voor, watrvoor in dien tijd de wereldnarktprijs mag iangenomen worden op 20 gulden := 50 peseta's per 100 kilo. De prijs van 96 peseta's bestaat dus uit:

Wereldmarktprijs accijns. Surtaxewinst.

$50+20+26=96$ peseti's, waruit volgt dat bijna de volle surtaxe op de vreemde suiker op deu prijs wordt gezet.

Hoewel het niet duidelijk is, hoe het overvloedig voorbanden product uit de Spaansche koloniën, waarvan de surtaxe slechts 13.50 peseta's bedraagt, het opvoeren van den prijs tot die hoogte toelaat, toch moet deze uitkomst als juist aungenomen worden, daar ook andere suikersoorten op audere tijdeu op dergelijke resultaten wijzen. Als werkelijke premie voor de beetsuikerfabrikanten in Spauje wordt dus gevonden:

\footnotetext{
Accijnswinst Surtaxewinst.$$
16.67+26=42.67 \text { peseta's }=17.07 \text { gulden }
$$$$
\text { per } 100 \text { kilo productie. }
$$ 
Het żou nu zak zijn ook te berekenen de premie der fabrikasten var rietsuiker, wier productle in het Zuiden van Spanje gedurende ieder der beide laatste campagnes ongeveer 20.000 .000 kilo bedroeg, maar de gegevens tot deze berekening ontbreken. Wel wordt in de wet de aanslag dier fabrikanten bepaald op 5 pCt. van het gewicht van het riet, maar hoeveel het werkelijk rendemeint bedraagt, en of ook met de rietsuikerfabrieken een abonnement is afgesloten wordt in de voorhanden bronueu niet vermeld. De accijnswinst kan dus niet bepaald worden, terwijl daarentegen uit den aard der zaak de surtaxe den fabrikamten in dezelfde mate ten goede kount als aan de beetskiakerindustrie.

De toestand in Spanje lèvert een sterk sprekend vodrbeeld o.p van de dwaasheid; waartoe hiet prethiestelsel voert. Eent industrie, die op zich zelf unbestanbaar is, daar zij als grondstof een gewas moet gebruiken, waaruit slechts $6 \mathrm{pCt}$. stiker gewonnen korden, terwijl in audere landen de opbrengst het dubbele bedraagt, is in het leven geroepen en wordt in het leven gehouden door kunstmiddeleu, die aan de staatskas op aanzienlijke offers komen te staan. Welk bedrag die offers wel bereiken? Veronderstel, dat de L2.000.000 kilo suiker door de syndicaatsfabrieken geproduceerd, die het land aan accijns slechts opbrengen 400:000 peseta's, uit de Spaansche koloniën waren ingevoerd, dan zouden zij aan inkomend recht hebben opgebracht $\frac{12.000 .000}{100} \times 33.50=4.020 .000$ peseta's zonder dat de consumtieprijs hooger zou geweest zijn. Een meerdere bate dus van 3.620.000 peseta's of 1.448 .000 gulden; die zelfs voor een schatkist beter voorzien dan die van Spanje, niet te versmaden ware. En dit offer wordt gebracht voor eeu luttele productie van slechts 12.000.000 kilo, waarvan ten slotte wellicht niet eens de fabrikanten het voordeel trekken, wegens de onvoldoende qualiteit der grondstof. Want de Zuidelijke landen, ook Portugal en Italië wijzen er op, schijnen voor de cultuur der beetwortels niet geschikt te zijn.

Ten slotte nog het volgende overzicht van den staat van Spanje's suikerhandel :

Productie van beetsuiker in de campagne 1893-94:15.000.000 kilo Productie van rietsuiker in de campagne 1893-94:20.000.000 " 
Invoer van suiker uit de
Koloniën Cuba, Porto Rico
en de Philippijnen ') $\left\{\begin{array}{l}\text { in } 1891: 49.600 .000 \text { kilo } \\ \text { in 1892: 74. } 00.000 " \\ \text { in 1893: } 23.800 .000 " \\ \text { in 1894: 42.600.000" }\end{array}\right.$ Invoer van buitenlandsche bectsuiker . . . $1.300 .000 "$ Invoer van geraffiueerde suiker, onbekend, warschijnlijk nihil. Uitvoer van suiker, . . . . onbekend, wararschijnlijk nihil.

\section{PORTUGA L.}

In annsluiting op Spanje zij ook met een enkel woord gehandeld over Portugal, hoewel dit land geen suiker produceert, en dus eigenlijk buiten het kader dezer beschouwingen valt. In 1888 werd een poging in het werk gesteld om de beetsuikerindustrie in Portugal in te voeren. Aan den Berlijnschen ingenieur Goerz werd in dat jaar het monopolie voor de fabricage van beetsuiker gedurende 11 jaren gegeven, onder voorwaarde, dat de productie na 5 jaren 10 millioen en na 7 jaren 20 millioen kilo suiker per jaar zou bedragen. Het schijnt echter, dat de toen aangewende pogingen tot geen resultaat hebben geleid, althans van geenerlei suikerproductie in Portugal vindt men melding gemaakt. De vroeger op Madera bestaande rietsuikerindustrie werd omstreeks 1888 door een ziekte in het riet ten gronde gericht, en heeft zich thans slechts in zooverre hersteld, dat het eiland in eigen behoefte aan suiker voorziet. Niettegenstaande het invoerrecht in Portugal voor suiker uit Madera slechts één vierde bedraagt van dat uit andere landen, schijnt de invoer geen voordeel op te leveren, wel een bewijs op hoe lagen trap deze industrie staat.

De belasting op de suiker bestaat uit een hoog inkomend inkomend recht, bedragende :

Voor geraffineerde suiker boven No. 20:145 reis per kilo 38.57 gulden per 100 kilo. ${ }^{2}$ )

Voor alle andere suiker 120 reis per kilo of 31.92 gulden per 100 kilo.

1) Wegens de zeer niteenloopende cijfers zijn de opgaven voor vier achtereenvolgende jaren gedaan.

2) 1000 reis zijn gerekend op 2.66 gulden. 
Voor melasse en dergelijke producten 60 reis per kilo of 15.96 gulden per 100 kilo.

$\mathrm{Bij}$ de bovenverınelde concessie was bepaald, dat tusschen den accijns, door den concessionaris te betalen, en het invoerrecht een verschil zou bestaan van minstens 50 reis per kilo zegge 13.30 guldeu per 100 kilo, welk bedrag dus ten volle den concessionnaris als premie ten goede zou komen. Dit cijfer is aangehaald om an te duiden hoe hoog de bescherming werd opgevoerd, zonder dat de Portugeesche beetsuikerindustrie zich kon ontwikkelen.

In 1891 hadden de volgende in- en uitvoeren plaats:

Invoer van suiker. . . . . 25.3 millioen kilo.

Uitroer van suiker. . . . . 0.6 " "

Het grootste gedeelte der ingevoerde suiker komt in de statistieken voor onder de benaming: "niet gespecificeerde suiker", zoodat niet kan worden nagegaan welk gedeelte daarvan geraffineerd werd ingevoerd; waarschijnlijk bestaat echter verreweg het grootste deel van den invoer uit ruwe suiker, die dus in Portugal geraffineerd wordt, waartoe ook de invoerrechten tendeeren.

\section{T A L I Ë.}

In Italië wordt de aanslag der beetsuikerfabrikanten bepaald naarkenze der fabrikanten, hetzij volgens de werkelijke productie, hetzij volgens de hoeveelheid en de dichtheid van het verwerkte sap. De eerste wijze van aanslag vindt geen toepassing, zoodat alleen de tweede hier ter sprake behoeft te komen. Hierbij is de anslag per hectoliter en per graad dichtheid van het gezuiverde sap vastgesteld op 1500 gram suiker $2^{\text {de }}$ klasse (No 20 en daar beneden). Deze suiker betaalt aan accijns 59.95 lires per 100 kilo. Voor de mate vau de accijnswinst, die in deze regeling ligt opgesloten, zijn geen gegevens beschikbaar en met het oog op de onbekende qualiteit der Italiaansche beetwortels en de mede onbekende wijze van werken in Italië, is het niet raadzaam zich aan een taxatie te wagen. Het invoerrecht voor suiker $2^{\text {de }}$ klasse bedraagt 88 lires per 100 kilo, waaruit dus een surtaxe volgt van 28.05 lires, welke surtaxe geheel ten goede komt ann de fabrikanteu 
en dus met de onbekende accijnswinst hunne premie vormt. ') Overigens bedroeg de geheele suikerproductie in Italië, door slechts twee fabrieken vertegenwoordigd, in 1893 niet meer dau 1.146.000 kilo, zoodat zij van geringe beteekenis en slechts weinig de aandacht waardig is.

Daarentegen zijn de Italiaansche raffinaderijen van groot belang, daar bijna al de in Italië voor de cousumtie benoodigde suiker, als ruwe suiker ingevoerd en in het land zelf geraffineerd wordt. Dit resultaat is verkregen door een niet onbelangrijke bescherming der raffinadeurs, die bepaald wordt door het verschil tusschen het invoerrecht van ruwe en geraffineerde suiker (2e en $1^{\mathrm{e}}$ klasse). ${ }^{2}$ ) Sedert December 1894,

1) Bij de wet van 8 Ang. 1895 is het boven bedoelde accijnsbedrag van 59.95 lires verhoogd tot 67.20 lires, zoodat daarmede de surtaxe tot 20.80 lires is rerminderd.

2) Dat de Italiaansche raffinadeurs werkelijk den prijs van hun geraffineerd kunnen opvoeren tot den wereldmarktprijs plus de surtaxe op geraffineerd, mag uit de volgende berekening worden afgeleid :

In 1893 was de wereldmarktprijs voor geraffineerde suiker gemiddeld 22 gulden $=50$ lires p. 100 kilo $(1$ lire $=0.44$ gulden $)$. In dien tijd was het invoerrecht op geraffineerde suiker 94 lires, maakt te zamen 144 lires, terwijl de middenprijs te Livorno in 1893 volgens de opgaven heeft gevarieerd tusschen 137 en 144 lires. Deze uitkomsten komen vrij wel overeen, vooral wanneer in aanmerking genomen wordt, dat groote fluctuaties in den wisselkoers in dit jaar in Italië plaats hadden, en in den loop van het jaar de bepaling gemaakt werd, dat alle invoerrechten in goud of zilver moesten betaald worden. Wenscht men echter verdere contrôle, dan kunnen ook de berekeningen voor 1890 en 1891 worden overgelegd:

1890. Wereldmarktprijs geraff. 19.50 gulden $=.44 .32$ lires

Invoerrecht.

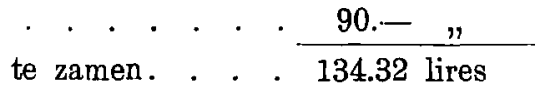

wordt genoteerd te Livorno. . . . . 132 à 134 lires

1891. Wereldmarktprijs geraff. 20.40 gulden $=. \quad 46.36$ lires

Invoerrecht. . . . . . . . . . . 90.- "

te zamen. . . . 136.36 lires

wordt genoteerd in de eerste maanden . 127 à 129 lires

later . . . 134 à 136 , 
bedragt het invoerrecht op ruwe suiker $S 8$ en op geraffineerde 99 lires per 100 kilo, warbij als grens tusscheu de beiden sooten is aangenomen suiker $\mathrm{n}^{\prime \prime} 20$. Deze greus is dus zeer hoog gesteld, waarvan het gevolg is, dat meest suiker van groote zuiverheid als ruw wordt ingevoerd en het rendement der raffinadeurs op niet minder dan $97 \mathrm{pCt}$. wordt aangenomen.

De raffinadeurspremie zal dus zijn:

$99-\frac{100}{97} \times 88=8.28$ lires of 3.64 gulden per 100 kilo. Onder dit, zoowel als onder het voorafgaande régime ') hebben de Italiaansche raffiuadeurs zich de buitenlandsche concurrentie van den hals kunneu houden en een aanzienlijken bloei bereikt.

De toestand in Italië wordt door de volgende cịfers aangeduid :

1893.

Millioen Ko. Millioen Ko.

Binnenl. productie v. beetsuiker (v. 90 pCt.) $\quad 1.1 \quad 2.1$

Invoer van ruwe suiker (v. 94.5 pCt) $77.8 \quad 72.5$

Invoer van geraffineerde suiker $\quad 2.4 \quad 2.8$

Uitvoer van suiker Nihil. Nihil.

\section{E N G E L A N D.}

Een geheel eenige plaats op de suikermarkt der wereld bekleedt Engeland, waar sedert 1874, alle rechten op de suiker zijn afgeschaft. In Engeland geen accijns. geen invoerrechten, geen premiën. Wat is uit dien exceptioneelen toestand voor Engelands suikerhandel geboren? Bij de beantwoording dier vraag valt in de eerste plaats te wijzen op de afwezigheid eener binnenlandsche beetsuikerindustrie. De op zich zelf kerngezonde toestand in Engeland moest onder den invloed

1) V66r Deeember 1894 was het invoerrecht op ruw 80.75 en op geraffineerd 94 lires. De nooden der Italiaansche schatkist hebben tot de verhooging aanleiding gegeven. De grens tusschen beide soorten was toen echter lager gesteld, namelijk suiker van 98 polarisatie. Bij dien toestand berekende men, dat het raffinadeursrendement was $94 \mathrm{pCt}$, zoodat de premie: $94-\frac{100}{94} \times 80.75=8.10$ lires, ongeveer dezelfde was als thans. 
van de gerugsteunde industrie op het continent tot dit resultaat leiden. Maar hier tegenover staan belangrijke voordeelen, waaronder bovenal de lage prijs der suiker in Engeland, waardoor een gewaardeerd voedingsmiddel onder ieders bereik gesteld is; daarbij voegen zich al die voordeelen, welke voortspruiten uit de uitbreiding van het binnenlandsch handelsverkeer en van het in Engeland belangrijke bedrijf der raffinaderijen van ruwe suiker. Fngeland is het land geworden, waarheen de overproductie van het continent afvloeit: heeft men hier de voordeelen eener industrie, dáar heeft men, ten koste van de vreemde consumenten en tresoriën, de voordeelen van een goedkoop volksvoedingsmiddel.

De volgende cijfers, geldende voor 1894, kunnen een overzicht geven van den toestand in Engeland:

Invoer van rietsuiker . . . . . . 346.7 millioen kilo.

Invoer van betsuiker. . . . . . 368.6 " "

Invoer van geraffineerde suiker. . . 695.8 " "

Uitvoer van ruwe suiker. . . . . $19.7 "$ "

Uitvoer v. binnenl. geraffineerde suiker 51.9 " "

Uitvoer v. buitenl. geraffineerde suiker 6.6 " "

Uit deze cijfers blijkt, dat de exporthandel in suiker betrekkelijk van geen grooten omvang is, maar dat de enorme hoeveelheden ingevoerde ruwe en geraffineerde suiker voor verreweg het grootste gedeelte in het land blijven, om daar geconsumeerd te worden, waardoor de consumtie per jaar en per hoofd der bevolking is gestegen tot 38.5 kilo, dat is ruim het vijfvoud van de consumtie per jaar en per hoofd der bevolking van het continent van Europa (7.4 kilo).

\section{VEREENIGDE STATEN VAN NOORD-AMERIKA.}

Aan deze beschouwingen, die overigens slechts tot den toestand in de Europeesche landen zullen beperkt worden, dienen toch eenige mededeelingen te worden toegevoegd omtrent de Vereenigde Staten van Noord-Amerika, eensdeels wegens den belangrijken invloed van den suikerhaudel dezer Staten op dien van Europa, ten anderen wegens de energisch werkende maatregelen, die in Amerika ter ondersteuning der industrie zijn toegepast. 
Hoewel de bepalingen omtrent de belasting der suiker en de bescherming der sujkerindustrie in de Mac-Kinley wet, die 1 Juli 1891 in werking trad, sedert de laatste helft van het vorige jaar vervangen zijn door een nieuwe wetgeving, zoo zal het toch noodig zijn deze bepalingen hier in hoofdpunten aan te teekenen, omdat de later te vermelden resultaten onder die wet verkregen zijn, en ter beooreeeling van de wijzigingen, die in den toestand te verwachten zijn onder de nieuwe regeling.

De bescherming der Amerikaansche ruwsuikerindustrie bestond onder de Mac-Kinley wet in een zeer hooge premie, niet op den uit voer zooals in andere landen, maar op de productie, terwijl de binnenlandsche consuntie door geen accijns bezwaard werd. Deze premie bedroeg:

2 cents per pond $\left.{ }^{1}\right)$ (11.02 gulden per 100 kilo) voor suiker, polariseerende $90 \mathrm{pCt}$. en daarboven.

1.75 cent per pond (9.64 gnlden per 100 kilo) voor suiker, polariseerende $80-90 \mathrm{pCt}$. (excl.).

De invoerrechten waren geregeld als volgt:

0.5 cent per pond ( 2.76 gulden per 100 kilo) voor suiker boven No. 16.

0.6 cent per pond ( 3.31 gulden per 100 kilo) voor suiker boven No. 16, die in het land, waar zij vervaardigd is, een hetzij directe of indirecte uitvoerpremie geniet.

Suiker, niet boven No. 16, vrij.

Door dit tarief van invoerrechten werd de ruwe suiker eigenlijk niet getroffen, want deze kon, voor zoover $\mathrm{N}^{\circ} .16$ of lager vrij worden ingevoerd en tot den invoer van deze soort kon men zich beperken. Bij het Mac-Kinley systeem kan dus geen surtaxe op de ruwe suiker worden aangenomen, maar bestond de bevoordeeling van het binnenlandsche product uitsluitend uit een reusachtige open premie op de geheele productie. Daarentegen sloot het tarief van invoerrechten een belangrijke bescherming der raffinadeurs in zich, want, daar de invoer van geraffineerde suiker (vallende onder de rubriek suiker boven $N^{\circ}$. 16) met 2.76 a 3.31 gulden per 100 kilo belast was, konden de Amerikaansche raffinadeurs met dit volle bedrag de

1) 1 Amerikaansche cent $=0.02 \frac{1}{2}$ gulden. 1 Amerikaansch pond $=0.4536$ kilo.

Econ. 1895. 
prijzen hunuer suiker verhoogen zonder buitenlandsche concurrentie te vreezen te hebben. De invoer van geraffineerd was dan ook zeer gering, zooals blijkt uit de onder aangevoerde cijfers, die de resultaten aanduiden, welke het Mac-Kinley systeem heeft opgeleverd ten opzichte van eigen productie, invoer en uitvoer.

1893.

Millioen kilo, Millioen kılo,

Productie der Ver. Staten v. N. Amerika.

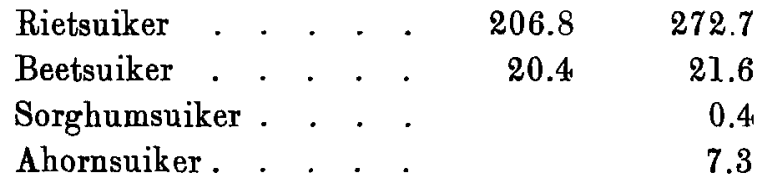

Invoer der Ver. Staten van N. Amerika.

$\begin{array}{lrrrrr}\text { Rietsuiker . . . . . } & \text {. } & 1424.9 & 1666.3 \\ \text { Beetsuiker . . . . . } & \text {. } & 242.5 & 141.0 \\ \text { Geraffineerde suiker } & . & . & 19.2 & 21.7\end{array}$

Uitvoer der Ver. Staten v. N. Amerika.

Ruwe suiker. . . . .

Geraffineerde suiker . .

De binnenlandsche industrie voorziet dus slechts voor een klein gedeelte in de consumtie en van dat gedeelte komt slechts een minimum hoeveelheid op rekening der beetsuiker, terwijl de overige productie in hoofdzaak bestaat uit rietsuiker der Zuidelijke Staten. De opgaven voor den invoer duiden eveneens een aanmerkelijk surplus van de rietsuiker boven de beetsuiker aan. Bij den zeer geringen invoer van geraffineerd blijkt eindelijk nog de groote belangrijkheid der raffinaderijen van Amerika, die de gezamenlijke productie en invoer van ruwe suiker, zeg rond 2000 millioen kilo in het jaar hebben te verwerken.

Zóó wạs de toestand tot in het laatst van 1894, toen een nieuwe wet tot regeling van dit onderwerp een geheele omwenteling kwam brengen in het bestaande systeem. De gezamenlijke zoo belangrijke premiën werden geheel afgeschaft en voor het tarief van invoerrechten een ander in de plaats gesteld op geheel verschilleude leest geschoeid. De ruwe en geraffineerde suiker werden bij den invoer belast met een bedrag van 40 
pCt. der waarde; de geraffineerde suiker (nl. die boven $\mathrm{n}^{\prime \prime}$ 16) bovendien nog met $\frac{1}{8}$ cent per pond (0.69 gulden per 100 kilo); en eindelijk werd een extra recht van $i_{i}^{-}$cent per pond $(0.55$ gulden per 100 kilo) gelegd op de suiker, komende uit landen, die hetzij directe of indirecte exportpremiën toestaan. 1) Bij de waardebepaling wordt rekening gehouden met den actueelen marktprijs; als grondslag wordt de factuurwaarde aangenomen, onder contrôle echter van rijkswege, waartoe van de ingevoerde partijen monsters genomen en polarimetrische onderzoekingen gedaan worden.

Eenige aanwijzingen mogen hier nog volgen omtrent hetgeen in dit nieuwe systeem ligt opgesloten met betrekking tot den toekomstigen gang van zaken in de Vereenigde Staten. Daartoe zij allereerst opgemerkt, dat, daar de binnenlandsche ruwsuikerindustrie op verre na niet in de behoefte van het land voorziet, overeenkomstig het reeds herhaaldelijk hieromtrent aangevoerde, het volle invoerrecht mag geacht worden in de plaats van de vroegere premiën ten bate van de fabrikanten op te treden. Om na te gaan in hoeverrre dit werkelijk het geval is, zijn een aantal noteeringen opgemaakt voor London en $\mathrm{New}$-York, waarbij voor beide steden ruwe suiker van omtrent 88 pCt. titrage genomen is (voor New.York: fair refining muscovadas 89 pCt.).

1) Ten opzichte van de indirecte premiën is hieraan de nadere bepaling toegevoegd, dat de importeur van suiker, die in een vreemd land vervaardigd is, welks regeering premiën betaalt, de verhooging van $i^{\frac{1}{0}}$ cent $\mathrm{p}$. pond nie.t verschuldigd is, in geval hij een certificaat van de regeering van dat land overlegt, waaruit blijkt, dat geen indirecte premie op die suiker verleend is, grooter dan de accijns op de beetwortels of het suikerriet, waaruit zij geproduceerd is. Door duidelijkheid munt deze bepaling niet uit en de „Board of General Appraisers \&, aan wien de beslissing is of de geïmporteerde suiker al of niet in de termen der verhooging valt, heeft hierbij heel wat moeielijkheid ontmoet.

Aanteekening verdient, dat genoemd lichaam de uitspraak heeft gedaan, dat Nederland noch direct, noch indirect een premie op den uitroer van suiker betaalt (!) en de rerhooging voor Nederlandsche suiker dus niet moet plaats hebben. 


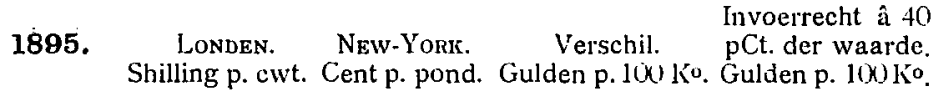

\begin{tabular}{|c|c|c|c|c|}
\hline 8/15 Maart & 9,2 & $2.1 \frac{1}{6}$ & 3.81 & $4.4,0$ \\
\hline 5/12 April. & $9 / 2 \frac{1}{2}$ & $2 . \frac{1}{16}$ & 3.76 & 4.42 \\
\hline $3 / 10 \mathrm{Mei}$ & $10 /$ & $2 . \frac{15}{6}$ & 4.19 & 4.80 \\
\hline 31 Mei/3 Juni. & $10 / \frac{1}{4}$ & $2.1 \frac{5}{6}$ & 4.17 & 4.81 \\
\hline 28 Juni/5 Juli. & $9 / 8$ & $2.1 \frac{3}{16}$ & 3,90 & $4.6 ; 4$ \\
\hline 26 Juli/2 Aug. & $9 / 9 !$ & 2.7 & 4.13 & 4.69 \\
\hline $23 / 30 \mathrm{Aug}$ & $9 / 4 !$ & $2 \cdot \frac{7}{3}$ & 4.60 & 4.50 \\
\hline 20/27 Sept & $10 / 2 \frac{1}{2}$ & 3.1 & 4.97 & 4.90 \\
\hline 18/25 Oct. & $10 / 7$ & $3 . \frac{3}{16}$ & 4.87 & 5.08 \\
\hline
\end{tabular}

Dat de verschillen in deze lijst niet volmaakt gelijk ziju aan de invoerrechten spreekt van zelf, daar nog andere kleinere factoren. op de verschillen van invloed zijn; toch is de overeenstemming alleszins voldoende om de conclusie te rechtvaardigen, dat in de Vereenigde Staten de bescherming der ruwsuikerfabrikanten gelijk is aan de surtaxe, d. i. hier gelijk aan het invoerrecht op ruwe suiker. Voor den tegenwoordigen tijd (laatst October 1895) worde die dus aangenomen op 5.08 gulden per 100 kilo ruwe suiker. Bij de oude regeling bedroeg zij 11,02 gulden, zoodat zij door de wet van 1894, tot minder dan de helft is gereduceerd.

Hoe staat het nu met de raffinadeurs? De protectie, die deze genieten wordt bepaald door het verschil tusschen het invoerrecht van geraffineerd en ruw. Neemt men voor den tegenwoordigen marktprijs van "granulated" aan 16.30 gulden per 100 kilo, dan wordt het invoerrecht à 40 pCt.: 6.5. gulden, waarbij nog het extrarecht van $\frac{1}{8}$ cent per pond, d. i. 0.69 gulden per 100 kilo moet gevoegd worden, maakt te zamen 7.21 gulden. Het invoerrecht van de hoeveelheid ruwe suiker, benoodigd voor de vervaardiging van 100 kilo geraffineerd bedraagt, het raffinage verlies op 10 pCt. aangenomen, $\frac{100}{9} \times 5.08=5.64$ gulden; het verschil is dus $7.21-5.64=1.57$ gulden, terwijl dit vroeger 2.76 gulden bedroeg, waardoor dus ook een niet onbelangrijke vermindering der bescherming wordt aangetoond. Intusschen zij opgemerkt, dat deze bescherming grooter wordt, naarmate men komt in de duurdere soorten geraffineerd, daar deze meer invoerrecht betalen, zonder dat voor de grondstof 
meer betaald wordt. De inate der raffinadeurs-protectie is dus ook hier: onmogelijk in cijfers uit te drukken.

Het is een tafereel, dat aan verwarring en wanorde niets te wenschen overlaat, warop getracht is in deze bladzijden het licht te laten vallen: een tafereel, dat aan den chaos herinneren zou, ware het niet, dat men moeilijk het denkbeeld van chaos kan vasthechten aan een kunstmatigen toestand, die gekweekt is door een langjarig knutselen, plooien en hervormen. Wenscht men nogmaals den blik te laten gaan over het geheele tafereel, het achterstaande overzicht moge daartoe dienen.

Ten overvloede zij vooraf opgemerkt, dat, mogen in dit overzicht de cijfers voor de bescherming, als het resultaat van berekeningen, centen en zelfs fracties van centen vermelden, de bedoeling slechts is globale, benaderde waarden aan te duiden.

Indien het totaalcijfer van 110.8 millioen gulden voor de hescherming, die in de Europeesche Staten aan de beetsuikerindustrie verleend wordt, het elders daarvoor berekende ') à 60 millioen gulden, verre overtreft, vindt dit hierin zijn grond, dat bij laatstbedoelde uitkomst geen rekening is gehonden met de beseherming, die voortvloeit nit de surtaxen. Toch dient ook deze zeer zeker in anmerking genomen te worden, daar zij even goed ten bate kount der fabrikanten als de eigenlijke premie en door hen genoteh wordt ten koste van de consumenten, of wel, zoo men wil, van de startskas, die de invoerrechten mist.

Bijzondere opmerking verdient nog, dat in bovenstaand overzicht slechts is rekening gehouden met de ruwsuikerindustrie. Omvatte het de geheele suikerindustrie in Suropa, waren daarbij dus ook in aanmerking genomen de winsten, die door de raffinadeurs in verschillende landen

1) 0. a. in de vóór eenigen tijd verspreide circulaire van den heer Lubbock, te Londen. 
II

员罂:

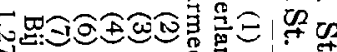

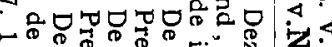

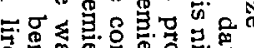

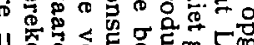

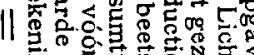
OS. ton on

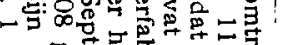

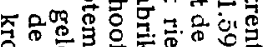

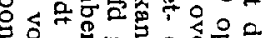
10.

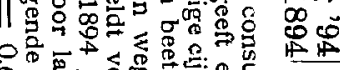
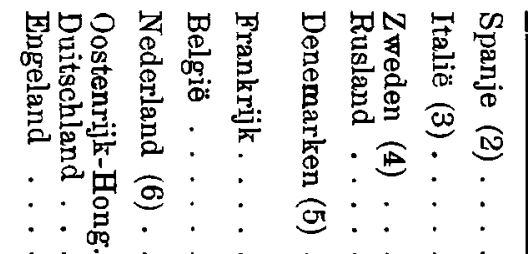
О人

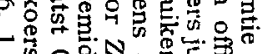

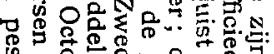

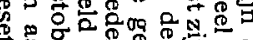

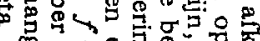
||

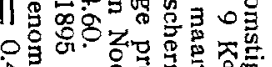
古曋 -1

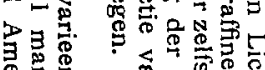

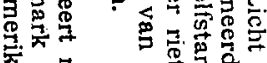

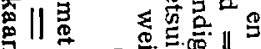

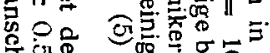
谜

ᄋ・

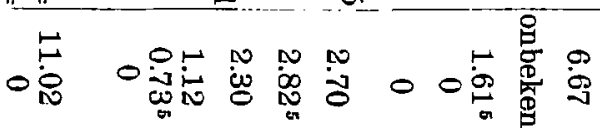

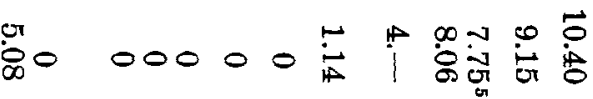

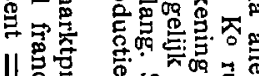

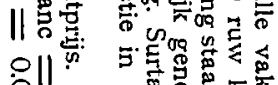
당

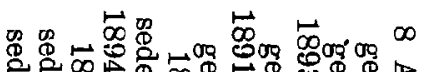
D

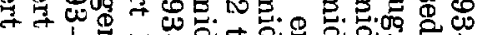

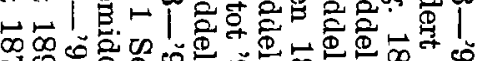

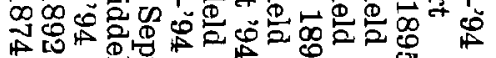
央

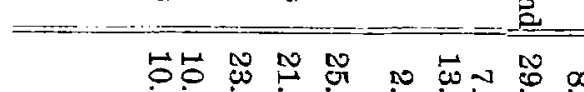
○ $\circ$ 过念 oै

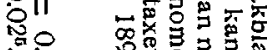
省

$\stackrel{8}{8}$ OD

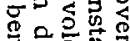

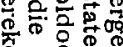

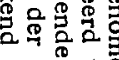

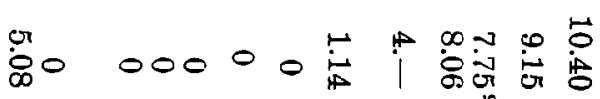
$\angle \sigma^{\circ} \leqslant g$

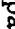

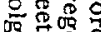

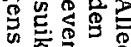

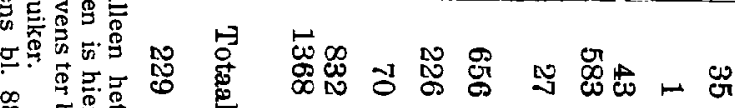

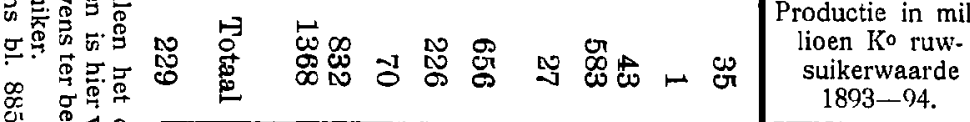
1893-94.

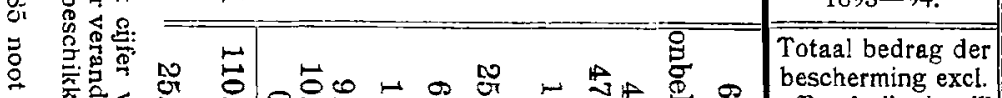
gulden in het jaar. 
ten gevolge van het premiestelsel, maar vooral van de surtaxen behaald worden, dan zou het eindcijfer een nog veel hooger bedrag aantoonen. De onmogelijkheid om deze winsten voor ieder land, ook maar benaderend in een totaal cijfer uit te drukken, weerhield echter de opname daarvan in een generaal overzicht.

Dit overzicht beperkt zich dus tot de beetsuikerprotectie en wijst de plaats aan, die iedere suikerproduceerende staat van Europa inneemt in de rij der zondaars op dat gebied, en claarmede ook de plaats, welke ons land in die rij bekleedt. De beantwoording der vraag wier oplossing het doel was dezer bijdrage is daarmede, onder volle erkenning der overblijvende leemteu, gegeven. Verdere conclusiën mogen aan den lezer worden overgelaten, wien deze bladzijden aangeboden zijn, meer als een verzameling en samenstelling van gegevens, dan als een onderhoudende lectuur.
A mst e rdam.
J. J. REESSE. 